\title{
Thin Films for Advanced Glazing Applications
}

\author{
Ann-Louise Anderson ${ }^{1}$, Shuqun Chen ${ }^{1}$, Luz Romero ${ }^{1}$, Işıl Top ${ }^{1}$ and Russell Binions ${ }^{1,2, *}$ \\ 1 School of Engineering and Materials Science, Queen Mary University of London, Mile End Road, \\ London E1 4NS, UK; a.anderson@qmul.ac.uk (A.-L.A.); shuqun.chen@qmul.ac.uk (S.C.); \\ 1.m.romeronunez@qmul.ac.uk (L.R.); i.top@qmul.ac.uk (I.T.) \\ 2 Materials Research Institute, Queen Mary University of London, Mile End Road, London E1 4NS, UK \\ * Correspondence: r.binions@qmul.ac.uk; Tel.: +44-20-7882-5305
}

Academic Editor: Somayeh Asadi

Received: 31 May 2016; Accepted: 9 September 2016; Published: 15 September 2016

\begin{abstract}
Functional thin films provide many opportunities for advanced glazing systems. This can be achieved by adding additional functionalities such as self-cleaning or power generation, or alternately by providing energy demand reduction through the management or modulation of solar heat gain or blackbody radiation using spectrally selective films or chromogenic materials. Self-cleaning materials have been generating increasing interest for the past two decades. They may be based on hydrophobic or hydrophilic systems and are often inspired by nature, for example hydrophobic systems based on mimicking the lotus leaf. These materials help to maintain the aesthetic properties of the building, help to maintain a comfortable working environment and in the case of photocatalytic materials, may provide external pollutant remediation. Power generation through window coatings is a relatively new idea and is based around the use of semi-transparent solar cells as windows. In this fashion, energy can be generated whilst also absorbing some solar heat. There is also the possibility, in the case of dye sensitized solar cells, to tune the coloration of the window that provides unheralded external aesthetic possibilities. Materials and coatings for energy demand reduction is highly desirable in an increasingly energy intensive world. We discuss new developments with low emissivity coatings as the need to replace scarce indium becomes more apparent. We go on to discuss thermochromic systems based on vanadium dioxide films. Such systems are dynamic in nature and present a more sophisticated and potentially more beneficial approach to reducing energy demand than static systems such as low emissivity and solar control coatings. The ability to be able to tune some of the material parameters in order to optimize the film performance for a given climate provides exciting opportunities for future technologies. In this article, we review recent progress and challenges in these areas and provide a perspective for future trends and developments.
\end{abstract}

Keywords: thin films; photocatalyst; self-cleaning; pollution reduction; energy efficient glazing; building integrated photovoltaics; thermochromic; vanadium dioxide

\section{Introduction}

There are an increasing number of tall glass fronted buildings for both residential and commercial purposes being built. This is principally driven by high land costs in urban centres as well as for aesthetic and comfort reasons [1]. The choice of materials for such buildings is to some extent driven by the mechanical limits of traditional materials such as brick, which may collapse under the weight of the building on top, or cost in the case of employing and maintaining external solid facades [2]. As such, extensive glass facades are a prominent feature in modern architecture for more than just aesthetic reasons. However, there are downsides to such features. For example, the energy demand of such a building will be high. Glass is a poor thermal insulator, as such the use of heating systems in cold climates and air conditioning systems in hotter climates results in higher electricity usage in order to 
maintain a comfortable internal environment [3]. This in turn leads to the greater increase in building energy demand and therefore a greater use of fossil fuels and higher emissions of carbon dioxide and other pollutant gases $[4,5]$. The growing amount of carbon dioxide emissions is contributing to the problem of global warming, hence increasing the need for alternative technologies to heating and air conditioning systems [6]. Increasing levels of airborne pollution also poses a significant problem as this may cause fouling of the windows to occur and block the transmission of visible light reducing the aesthetic and comfort aspects of the windows [7]. For taller buildings, this problem becomes more expensive and labour intensive to resolve and for low and mid-rise building leads to a more regular manual cleaning be required to maintain desirable window properties [8].

One strategy to address these challenges is the production of functional metal oxide thin films, which can be used as window glazing coatings to construct 'smart windows' (those that have additional layers that improve the performance or enhance the properties of the glazing unit). Such windows have greatest use within constant climates (i.e., those that are largely invariant, e.g., constantly below a comfortable room temperature) [3]. In cold climates windows with high solar transmittance and low thermal emittance are desirable. These allow solar radiation into a building but stop blackbody radiation from escaping and thus warming the building interior. In constantly hot climates, materials that are transparent in the visible region but reflective in the infrared, such as thin metallic coatings can be used to ensure the inside of the building remains cool. However, the materials used in these solutions often require large quantities of indium which is becoming increasingly scarce and more expensive; as such producing such coatings from these traditional materials is becoming unsustainable [9]. Further to this such coatings however, are unsuitable for variable climates such as in the United States of America and central Europe (amongst others) [10]. In these instances, materials that have variable properties that change depending on the local environment are a better solution. These chromogenic materials include several categories in response to an external stimulus, such as thermochromic materials whose properties change depending on their temperature [11].

Thin films of functional metal oxides may also be used to produce coatings of self-cleaning or pollution reducing materials. Such materials utilise sunlight to catalyse the breakdown of organic materials such as airborne pollutants derived from the burning of fossil fuels [8]. They have also been shown to breakdown problematic urban pollutant gases from internal combustion engines such as nitrogen dioxide [12]. Further to this, recent research has shown how thin film dye sensitized solar cells may be made semi-transparent and applied to glass. The potential benefit of such glazing is large, not only will some solar heat gain be absorbed, reducing heating and thus lowering the cooling load, but will also produce electricity that can further reduce the buildings external energy demand in an environmentally friendly manner [13].

This review will discuss some of the latest trends and research in self-cleaning and pollution reducing coatings, energy demand reduction and energy generation for building glazing that has appeared in the literature until early 2015.

\section{Self-Cleaning Glazing Applications}

Self-cleaning glass is a well-known technology that has been widely developed as a coating material for the external envelopes of buildings within the last decade. Although certain maintenance is required, self-cleaning glazing technology enables great labour saving as well as sustainability and less cleaning chemical products are needed [14].

The fast development of self-cleaning glazing can be partially attributed to the increasing demands of technologically competitive glazing which required the development of multifunctional coatings. In 2001, Pilkington Glass became the pioneer in commercialising self-cleaning windows with Pilkington Activ $^{\mathrm{TM}}$ (currently Activ Clear). This product was followed by some other types of self-cleaning glass with additional properties; for example, Pilkington Activ ${ }^{\mathrm{TM}}$ Blue and Pilkington Activ ${ }^{\mathrm{TM}}$ Bronze combine the benefits of the Pilkington Activ ${ }^{\mathrm{TM}}$ Clear coating on body tinted glass to provide some additional solar control to provide some additional solar control functionality to keep the inside of 
the building cooler. Likewise, Pilkington Activ Sunshade ${ }^{\mathrm{TM}}$ Neutral and Pilkington Activ Sunshade ${ }^{\mathrm{TM}}$ Blue offer enhanced solar control through the addition of the Pilkington Sunshade ${ }^{\mathrm{TM}}$ coating on the inner pane of the glass; ideal for conservatory roofs and walls. After the release of Pilkington Activ ${ }^{\mathrm{TM}}$, many other companies started to commercialise self-cleaning glazing as a product itself and also combined with solar control. This was the case for Bioclean ${ }^{\mathrm{TM}}$, which is a range of products released by Saint-Gobain Glass. There is a variety of products in the Bioclean ${ }^{\mathrm{TM}}$ range with low self-cleaning maintenance properties and high solar control performance $[15,16]$. Other products such as PPG's Sunclean ${ }^{\mathrm{TM}}$ [17] and Varidian Renew ${ }^{\mathrm{TM}}$ [18] self-cleaning coating can be used in conjunction with solar control glass.

Self-cleaning glazing is mainly divided into two categories: hydrophilic and hydrophobic. In both cases, the self-cleaning effect is produced through the action of water by forming water sheets (hydrophilic) or by forming rolling droplets (hydrophobic) that carries away dirt. Nonetheless, hydrophilic coatings have the additional property of breaking down the dirt on the surface under UV irradiation in a chemical process called photocatalysis.

Titanium dioxide is still considered the most suitable material for hydrophilic self-cleaning coating due to its high photocatalytic performance, transparency, chemical stability and low cost. Other coating materials such as vanadium oxide have been reported to show high photocatalytic performance [19] but their low optical transparency make them rather unsuitable for glazing applications. Attempts to improve titania photocatalytic performance have included doping with metals [20], co-doping [21] and coupling with highly conductive semiconductors such as graphene [22].

Hydrophobic surfaces for self-cleaning applications have also been extensively investigated [23,24]. However, these materials have not beaten the advantageous properties of titania thin film hydrophilic surfaces in terms of life expectancy and performance. Whereas hydrophilic surfaces can be used for at least 25 years, hydrophobic surfaces have a much shorter life expectancy of 3-4 years which has been attributed to a result of mechanical abrasion from weathering, necessary maintenance work and to the degradation nature of pollutants. Moreover, after some weathering and in contrast to hydrophilic surfaces, hydrophobic coatings may show poorer self-cleaning performance when compared to untreated float glass [25].

Generally speaking, self-cleaning surfaces encounter the same kind of limitations frequently related to durability, reduction of visual transmittance, functionality and instability at high temperatures [26]. Therefore, future research pathways should aim to overcome these limitations for commercial use in glazing.

\subsection{Fundamental Mechanisms in Self-Cleaning}

\subsubsection{The Hydrophobic Self-Cleaning Mechanism}

Hydrophobicity is strongly dependent on the surface topography and chemical structure. Cassie and Baxter [27] described a model in which the contact angle is determined by the surface free energies of solid-liquid, solid-gas and liquid-gas boundaries. For heterogeneous surfaces, any water droplet is not entirely in contact with the rough surface and some air bubbles will be trapped at the interface (Figure 1a). The self-cleaning mechanism arises from the poor contact area of dirt particles on the rough surfaces resulting in low adhesion forces. Dirt particles would be easily trapped by water droplets placed on the surface since capillary forces would prevail over adhesion forces of the particle and the surface and, as a result the dirt is washed away [28].

Neinhuis and Barthlott [29] accomplished the first comprehensive experimental study on the self-cleaning action of hydrophobic coatings by investigating different plants and contaminants. They described the hydrophobic self-cleaning process as the Lotus-Effect from the observations of the lotus leaves. Almost perfect spherical droplets of water form on the surface trapping the dirt that will be carried away before the water evaporates. It was observed that in smooth surfaces with high contact angles water droplets tended to disperse contaminants, whereas in rough surfaces with high contact 
angles, water droplets could trap contaminants and remove them from the surface. The difference between advancing and receding angles is known as hysteresis (Figure 1b) and ideally should be as close as possible to zero. In other words, low hysteresis angles mean that drops would roll easily along the surface at low surface inclination angles. Generally, it is considered that the requirements for a self-cleaning hydrophobic or superhydrophobic surface is a static contact angle $>160^{\circ}$ and a very low roll-off angle $\left(<10^{\circ}\right)$, i.e., the minimum inclination angle necessary for a droplet to roll off the surface [26].

a)

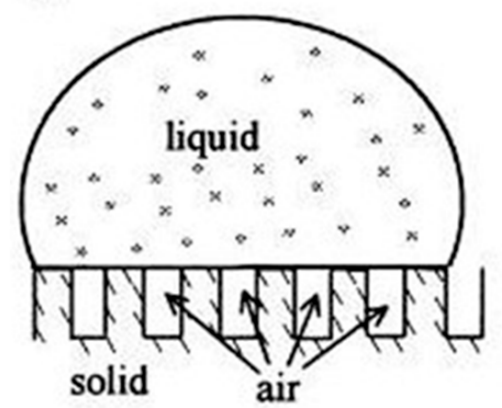

b)

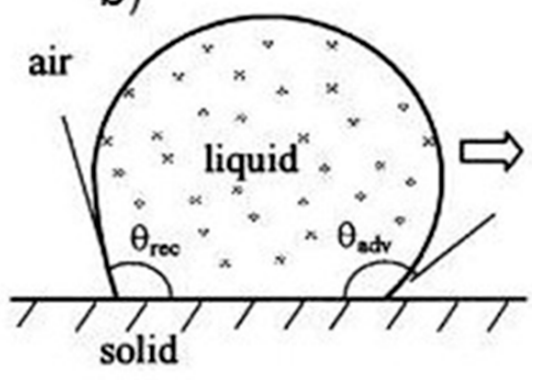

Figure 1. (a) Droplet over a patterned heterogenous surface; (b) definition of advancing $\left(\theta_{\text {adv }}\right)$ and receding $\left(\theta_{\text {rec }}\right)$ contact angles for a moving droplet on an inclined surface (hysteresis) [30].

\subsubsection{The Hydrophilic Self-Cleaning Mechanism}

Hydrophilic self-cleaning windows are coated with a thin transparent layer of titanium dioxide. The self-cleaning mechanism arises from the combination of two properties; photocatalysis and photo induced hydrophilicity. Thus, photocatalysis causes the chemical break down of the organic matter absorbed on the surface while photo induced hydrophilicity causes water to form sheets, which washes away dirt.

The self-cleaning mechanism can be explained by studying the $\mathrm{TiO}_{2}$ band gap under UV irradiation (Figure 2). When titania absorbs light with the same or greater energy than its band gap (3.2 eV for anatase and $3.0 \mathrm{eV}$ for rutile), an electron-hole pair is generated which may undergo recombination on the surface (a) or in the bulk of the semiconductor (b). On the surface the holes cause the oxidation of nearby organic molecules (c) while the electrons combine with atmospheric oxygen to generate superoxide radicals that also decompose such organic matter (d). This decomposition reaction typically gives $\mathrm{CO}_{2}$ and $\mathrm{H}_{2} \mathrm{O}$ as products. Likewise, the photo induced hydrophilicity or superhydrophilicity mechanism of titania can be explained by the photo-generated charge carriers. Mills et al. [31] argue that one of the possible mechanisms for this is that photo generated holes get trapped in the titania lattice thereby weakening the bond between titanium and oxygen. As a consequence, an oxygen vacancy is produced and thus the dissociative adsorption of water at the site to make it more hydroxylated. The resulted surface is unstable and, with time, when placed in the dark, the newly formed hydroxyl groups desorb to form hydrogen peroxide or water and oxygen- leaving an oxygen vacancy. Thus, the photo-induced superhydrophilic titania returns to its hydrophilic state when stored for a long time in the dark. 


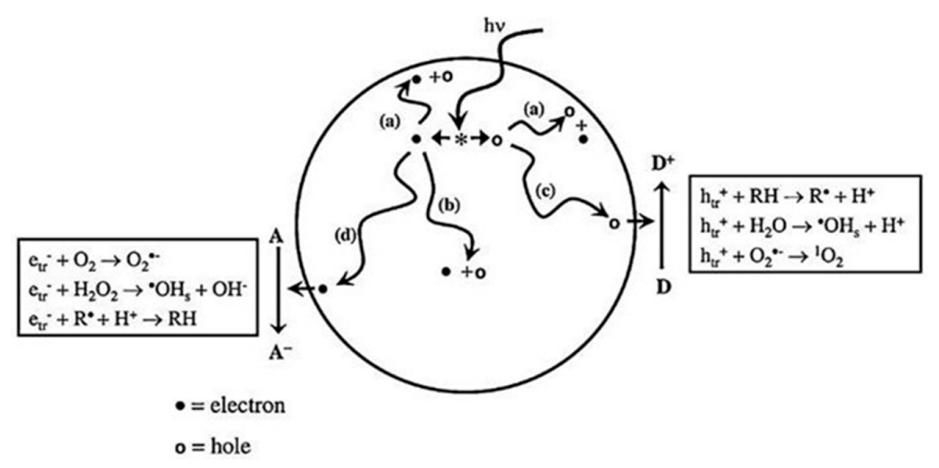

Figure 2. $\mathrm{TiO}_{2}$ photocatalytic mechanism [32].

\subsection{Hydrophilic Self-Cleaning Glazing Today}

The search for improvements in self-cleaning glazing has led to the investigation of new compounds with photocatalytic properties. The combination of hetero-nanostructures such as $\mathrm{AgCl} / \mathrm{BiOCl}$ [33] and $\mathrm{ZnO} / \mathrm{In}_{2} \mathrm{O}_{3}$ [34] by chemical co-precipitation methods have been reported to show high photocatalytic performance in the visible. Bismuth germanate compounds $\left(\mathrm{Bi}_{12} \mathrm{GeO}_{20}\right)$ [35] and other compounds such as $\mathrm{BaM}_{1 / 3} \mathrm{~N}_{2 / 3} \mathrm{O}_{3}(\mathrm{M}=\mathrm{Ni}, \mathrm{N}=\mathrm{Nb}, \mathrm{Ta})$ [36] have reported to give good photocatalytic performance but the potential for self-cleaning glazing is limited as they have been only studied in powder form. Many metal oxides and sulphides such as $\mathrm{WO}_{3}, \mathrm{ZnO}$ and $\mathrm{CdS}$ along with polyoxometallates have been also investigated over the years but none of these have showed better photocatalytic results than titania using light alone [8].

\subsubsection{Improvements in $\mathrm{TiO}_{2}$ Self-Cleaning Properties}

Novel methods such as electric field assisted chemical vapour deposition of $\mathrm{TiO}_{2}$ thin films have been shown to give excellent photocatalytic results (very fast dye degradation half-life values of $2.5 \mathrm{~min}$ ) by the induction of changes in the morphology and particle size of the semiconductor microstructure as well as changes in the crystal orientation [37]. In particular, it has been reported that the induction of AC electric fields produces more favourable modifications in titania thin films than DC electric fields [38]. Some other methods aim to increase the photo response in the visible light range such as the incorporation of nanoparticles into $\mathrm{TiO}_{2}$ coating, coupling with visible light absorber semiconductors and doping with different metals.

\subsubsection{Phase Separated Semiconductors}

The photo activity, as measured by organic material degradation, of $\mathrm{TiO}_{2}$ can be improved through integration with other photoactive materials to form phase-separated semiconductors as incorporated nanoparticles or as a separate layer forming hetero-nanostructures. In both cases, the enhancement of photocatalysis is produced by a compatible coupling of band gaps which favours the effective separation of charged carriers at the interfaces of coupling phases and an increase of the photo response in the visible [39]. Metal nanoparticles can be incorporated into $\mathrm{TiO}_{2}$ assisting photo-catalysis by separating charge carriers. Excited electrons are transferred from the conduction band of the semiconductor to the metal preventing recombination. Electrons accumulated on the metal particle surface can reduce adsorbed species and thus increase photocatalytic rate. At the interface, electrons and holes migrate between phases depending on the relative energies of their conduction and valence bands [8]. Incorporation of silver [40] and gold nanoparticles [41] to mesoporous titania coatings via sol-gel processes have reported to increase the photocatalytic rate by increasing the photo response of $\mathrm{TiO}_{2}$ in visible light. The exposure of nanoparticles to the medium may result in undesirable corrosion or dissolution of metals during repeating photocatalytic reactions which can be avoided by incorporating the metal into titania as core-shell nanocomposite [42]. 
Hetero-nanostructures formed by coupling titania with visible light absorbing semiconductors, such as bismuth based semiconductors, are another possibility to induce photocatalysis and super-hydrophilicity. Hierarchical flake-like $\mathrm{Bi}_{2} \mathrm{MoO}_{6}$ on $\mathrm{TiO}_{2}$ nanoparticle film substrate produced by the solvothermal process showed an important improvement of the photocatalytic performance by enhancing the visible light absorption [43]. This was attributed to a combination of controlled factors such as surface morphology and adequate coupling of both semiconductors band-gap. Bismuth based hetero-nanostructures have been reported as excellent photosensitizers due to their narrow band gap ( 1.4 eV) which allows light harvesting in the visible range. In addition, the conduction band energy is approximately $0.26 \mathrm{eV}$ higher than that of $\mathrm{TiO}_{2}$ [44] which allows for fast injection of photo-generated electrons from the bismuth based semiconductor into the $\mathrm{TiO}_{2}$ conduction band [43]. Hetero-nanostructures of other compatible materials in determined structures such as $\mathrm{Cu}_{2} \mathrm{O}-\mathrm{TiO}_{2}-\mathrm{ZnO}$ have been also reported to enhance photocatalytic properties by inducing interfacial states and energy band differentials, which favour electron transitions and inhibit photo-generated electron-hole recombination. In this study, it was observed that the photocatalytic performance of the hetero-nanostructure $\mathrm{Cu}_{2} \mathrm{O}-\mathrm{TiO}_{2}$ remarkably increased with the incorporation of $\mathrm{ZnO}$ nanoparticles on the surface which as attributed to an increase of surface area and active sites for photochemical reactions [45].

\subsubsection{Doping}

Non-metal doping using nitrogen $(\mathrm{N})$ or sulphur $(\mathrm{S})$ has been the most used method to reduce the titanium dioxide band gap in order to increase the absorption of visible light thus improving photocatalytic activity. However, doping has been found to be limited for self-cleaning applications due to an increase of recombination rates resulting in lower photocatalytic activity than pure $\mathrm{TiO}_{2}[46,47]$.

Nitrogen and fluorine co-doping have been reported to produce better photocatalytic performance than pure $\mathrm{TiO}_{2}$ [48]. This has been attributed to a synergy effect between the increase in absorption in the visible by $\mathrm{N}$-atoms and the formation of new active sites by F-atoms [49]. Transparent C-F-N co-doped titanium dioxide thin films produced by the sol-gel method have been reported to show strong visible-light absorption and high photocatalytic performance. In addition, the increase in surface roughness produced by the co-doping induced a superhydrophilicity even under dark conditions [48].

\subsection{Multifunctional Hydrophilic Self-Cleaning Coatings}

Current investigations aim to further develop integrated self-cleaning coatings with other materials mostly related to building energy cost saving. UV-light cut and low emissivity self-cleaning glazing can be achieved by integrating $\mathrm{CeO}_{2}$ and $\mathrm{TiN}$ with $\mathrm{TiO}_{2}$ via sol gel processing [50]. The benefits of integrating antireflective properties with self-cleaning coatings using typically sol-gel processing and sputtering processes have been reported [51-53]. It is well known that in photovoltaic cells glass transparency is strictly linked with efficiency which is believed to drop by $33 \%$ per $1 \mathrm{~g} / \mathrm{m}^{2}$ of dust accumulation on the surface [54]. Other studies on the combination of renewable power generation and destruction of air pollutants in urban environments reported gain of $2.65 \%$ after measurements under standard test conditions with antireflective glass [55].

\section{Hydrophilic Self-Cleaning Coatings Today}

Nanocomposites of $\mathrm{TiO}_{2}$ nanoparticles in silicon- based polymers produced by sol-gel processes have been reported to show excellent self-cleaning properties and good mechanical properties $[56,57]$ which make them highly suitable for outdoor applications. Similarly, nanocomposites produced from titanium and silicon alkoxides in the presence of oxalic acid have been reported to show excellent photocatalytic properties on stone with potential commercial applications as protective coatings of building materials $[58,59]$. Further investigations have integrated antireflective, water-repelling and self-cleaning properties from methyl modified $\mathrm{SiO}_{2}$ and $\mathrm{TiO}_{2}$ bilayer highly suitable for photovoltaic cells [23]. 


\subsection{Conclusion and Outlook for Self-Cleaning Glazing}

Although important developments have been made in self-cleaning glazing, there are still limitations with existing coatings such as durability, reduction in visual transmittance or function of coatings [26].

The heterogeneity of between the coating and the glass substrate is believed the main cause of the lack of durability of architectural materials [26] which companies such as St. Gobain or Pilkington try to overcome by fusing the coating to the glass substrate while it is molten during the online chemical vapour deposition. The pyrolytic deposition of the coating during the manufacturing process enables a strong chemical bond, which ensures higher durability.

Nevertheless, long-term stability is still a critical challenge for hydrophobic self-cleaning coatings [60]. The micro and nano-scale surfaces are more sensitive to mechanical stress than common surfaces. Affected surfaces can be repaired by passive generation; by self-assembly or active repair process. In the second approach particles are deposited at surface defects and their conglomerates replace the original structure and thus functionality is recovered. However, self-cleaning hydrophobic coatings still face short life expectancy (3-4 years) and low performance for outdoor applications. The main problem for hydrophobic self-cleaning coatings is the mechanical abrasion which is believed to decrease by enhancing hierarchical roughness (Figure 3) [61]. Thus, the Cassie state is stabilised by the presence of roughness at two different scales; robust micro-scale bumps that provide protection against mechanical abrasion to a nanoscale roughness, which ensures the non-wettability of the surface [61].

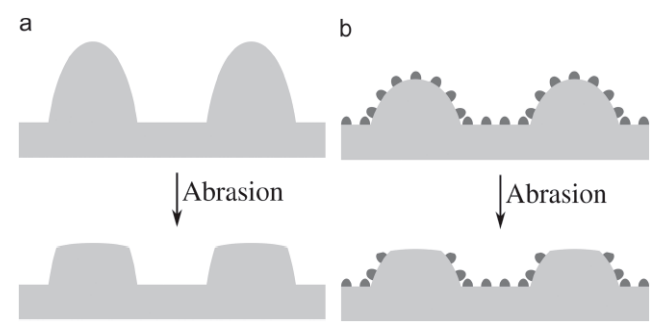

Figure 3. The effect of abrasion on surfaces with (a) micro roughness alone and (b) surface patterned with mechanically stable micro bumps with nano roughness [61].

There is a drive to develop new materials that have strong mechanical properties and great absorbance in the ultra-violet and, partially, in the visible spectrum to enhance photocatalysis. Some experts appoint that the development of strong transparent materials is the future in the glazing industry. These materials could be strong enough to replace frames in windows and used in spacers at the same time that allow light go through [25].

Further development of titanium dioxide thin films for self-cleaning applications should also address the breakdown of inorganic matter on the surface. The limited applications to the breakdown of organic matter (but not inorganic matter) make this kind of coating rather unsuitable for coastal areas where salt from sea mist can be deposited in the windows. As such additional cleaning would be necessary for good maintenance of the glazing [8,21]. Glazing for these types of areas also pose a challenge in terms of mechanical strength, as the impact of sand and other inorganic particles on the window surface can deteriorate the glazing much quicker.

However, one facet of the future of the glazing industry will be to produce multi-functional windows, which combine different materials with various functions. This kind of glazing could combine self-cleaning coatings not only with anti-reflection properties but also with chromogenic or photovoltaics properties, depending on the buyers' needs.

One of the most outstanding applications for self-cleaning surfaces is for use in building integrated photovoltaics (BIPV). This is considered a promising technology due to its dual action as both a building envelope material and a sustainable energy source. BIPVs integrated into windows are called solar glazing, and have the potential to significantly reduce the overall building material costs as well as the 
resulting building energy generation costs, by offsetting the amount of energy required in the building from non-sustainable sources i.e., fossil fuel burning power stations. However, the maintenance of this technology can be expensive, and this is where self-cleaning technology will prove very useful, as the accumulation of dirt affects the performance of photovoltaic cells. Thus, the integration of self-cleaning technology in solar glazing is highly desirable [25].

\section{Energy Efficient Glazing Applications}

The energy required for the heating and cooling of modern buildings accounts for around $40 \%$ of global energy consumption and $30 \%$ of all carbon dioxide emissions [58,59]. These numbers will continue to grow as more areas of the world become developed and more buildings are constructed [62-64]. A variety of approaches, such as installing more efficient heating (e.g., heat pump rather than electric hot water systems) [65] and renewable power systems (e.g., solar energy as a power source) [66], have been applied to reduce building energy demand. Moreover, the usage of energy efficient glazing is another important approach because untreated glass is a poor heat insulator whereby windows become a major heat transfer path between the inside and outside of buildings, resulting in unwanted heat transfer $[63,64]$. This is especially true in modern architecture, where a larger proportion of the exterior wall is designed and constructed with glass façades to be aesthetically pleasing and space efficient, but this also provides an additional challenge to its thermal efficiency [64].

Low emissivity (Low-E) and solar control windows are two types of widely used energy efficient glazing, specifically designed for cold and warm climate dominant areas, respectively. Windows with low thermal emittance are produced by depositing spectrally selective coatings on the glass surface, such as transparent conducting oxides (TCO) or thin metal films, which maintain their transparency in solar wavelength $(0.3$ to $2.5 \mu \mathrm{m})$ and reflective in thermal radiation range $(3.0$ to $50 \mu \mathrm{m})$. For solar control glazing, the coatings are required to be highly reflective since the beginning of near infrared pertinent $(0.7$ to $50 \mu \mathrm{m})$ and also transparent to the visible light $(0.3$ to $0.7 \mu \mathrm{m})[67,68]$, as illustrated in Figure 4.

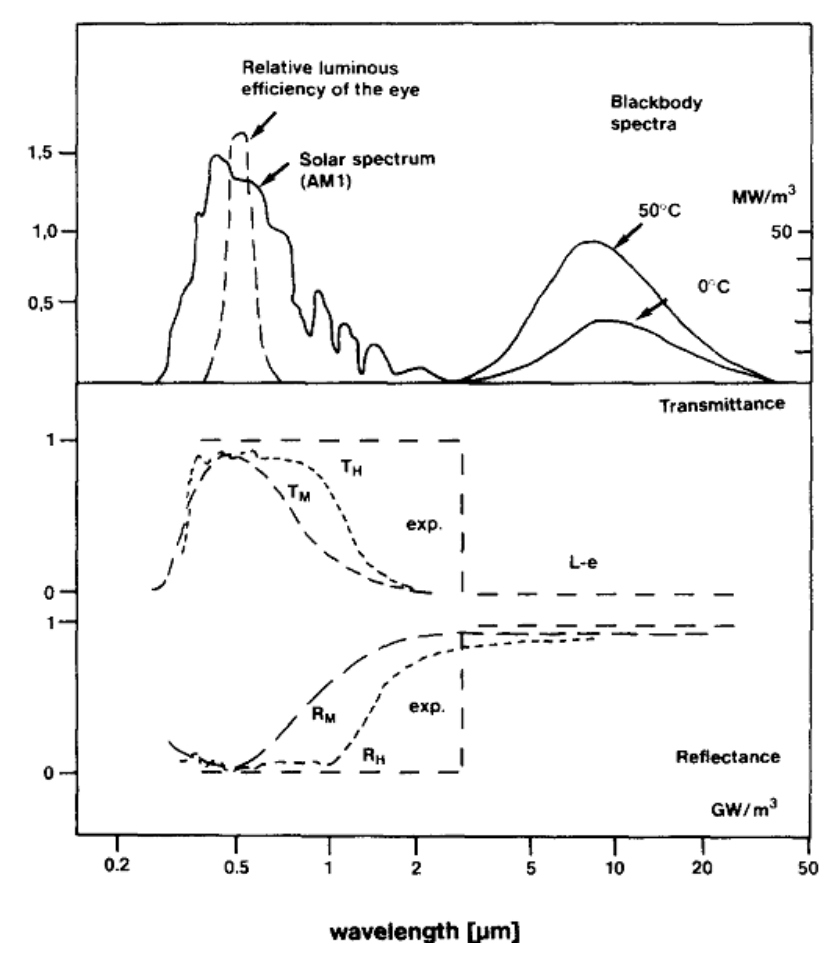

Figure 4. Solar irradiation spectrum, blackbody radiation spectra and characteristics for ideal low-E $\left(_{H}\right)$ and solar-control glass (M) [69] where T and R correspond to Transmission and Reflectance respectively. 


\subsection{TCO Materials as Energy Efficient Coatings}

Transparent conducting oxides can be used as energy efficient coatings if they have a wide band gap (usually greater than $3 \mathrm{eV}$ ) which enables them to transmit light in the visible spectrum and have a high carrier density $\left(10^{20}\right.$ to $\left.10^{21} \mathrm{~cm}^{-3}\right)$ that can induce plasma reflection at the beginning (solar control application) or middle (Low-E application) range of near infrared light.

Figure 5 shows the optical spectra of a typical Low-E TCO material, in addition to its good visible transparency, a decrease in transmission and increase in reflection can be observed at longer wavelengths $(>1500 \mathrm{~nm})$. This transition, corresponding to a maximum in absorption, is referred to as the plasma wavelength.

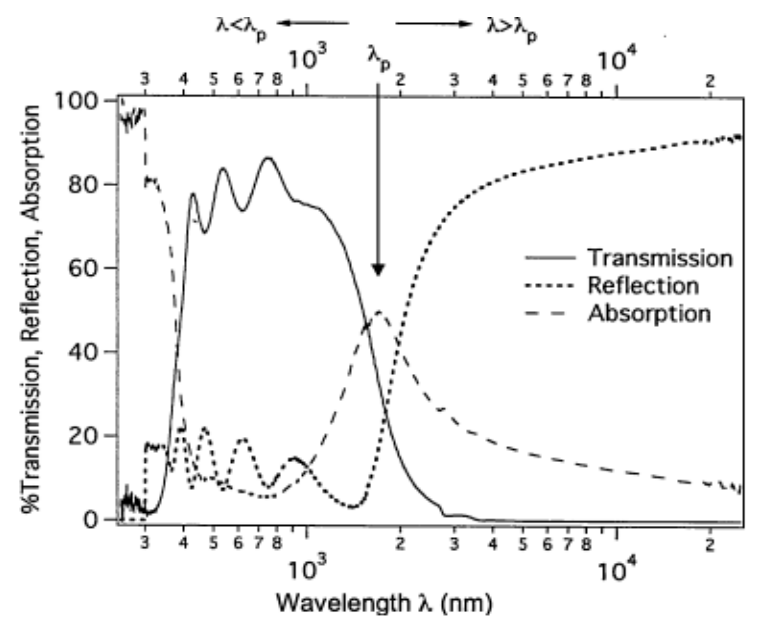

Figure 5. Transmission, reflection, and absorption spectra of a typical TCO [70].

Based on the above theories, a large number of doped wide band gap TCO materials can be used for energy efficient coatings. In the following part, three representative transparent conducting oxides, including tin-doped indium oxide (ITO), fluorine-doped tin oxide (FTO) and group-III elements (such as $\mathrm{Al}$ and $\mathrm{Ga}$ ) doped zinc oxide (AZO and GZO), are selected and we will introduce the existing application of these materials in glazing industry as well as recent research highlights.

\subsubsection{Tin-Doped Indium Oxide (ITO)}

As one of the most popular and earliest studied TCO materials, tin doped indium oxide films (ITO) often exhibit high electrical conductivity, optical transparency and infrared reflectance together, which make them attractive for use in a variety of applications from liquid crystal displays, transparent electrodes in solar cells to heating-reflecting mirrors [70,71].

High quality ITO coatings have been grown by several deposition techniques including magnetron sputtering [72,73], chemical vapour deposition (CVD) [74], sol-gel [75], spray pyrolysis [76], and pulsed laser deposition (PLD) [77] on a glass substrate. For example, Banerijee et al. reported the visible transmission and infrared reflection (at $2100 \mathrm{~nm}$ ) of magnetron-sputtered ITO films could reach $\sim 90 \%$ and $\sim 75 \%$, respectively [72]. In addition, high visible transmittance $(>80 \%)$ and infrared reflection $(\sim 70 \%$ at $2500 \mathrm{~nm})$ are observed in ITO thin films prepared by Aerosol Assisted CVD (AACVD) [74]. The plasma wavelength of ITO $(\sim 1800 \mathrm{~nm})$ is located in the middle range of near infrared light, so it is suitable for Low-E applications. Rydzek et al. fabricated ITO films with the sol-gel dip coating method and the resultant coatings exhibited good optical transparency $(>80 \%)$ and a low emittance value (0.19) [75]. Frank et al. reported that, in addition to the good visible transmittance $(>80 \%)$, the reflectance (at $1500 \mathrm{~nm}$ ) of spray-deposited ITO films could increase from $10 \%$ to more than $80 \%$ when the carrier density was enhanced from $5 \times 10^{20} \mathrm{~cm}^{-3}$ to $13 \times 10^{20} \mathrm{~cm}^{-3}$, accompanied by the plasma wavelength shifting from the middle $(\sim 1700 \mathrm{~nm})$ to the beginning range $(\sim 1120 \mathrm{~nm})$ of near 
infrared light, as shown in Figure 6 [76]. Moreover, from Kim et al.'s study, the carrier concentration in ITO films prepared by PLD could reach $8-13 \times 10^{20} \mathrm{~cm}^{-3}$ with high visible transmittance $(85 \%-90 \%)$ and infrared reflectance ( $75 \%$ to $85 \%$ at $2500 \mathrm{~nm}$ ) [77].

These results all support the use of tin-doped indium oxides as solar control or Low-E coatings, whereby it is easy to control the film performance by changing the deposition method and parameters (such as deposition temperature, film thickness and doping concentration) to meet different energy saving demands. Commercially, most ITO coatings for architectural glazing are deposited by vacuum sputtering, such as in the Yaohua ITO coated glass production line [78].

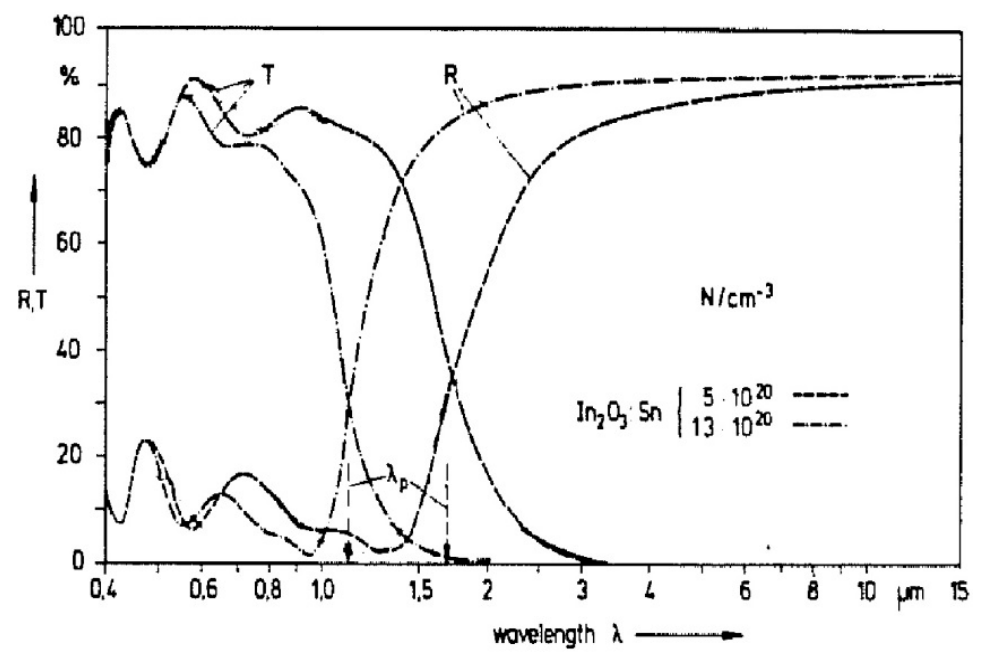

Figure 6. The transmittance and reflectance of $\operatorname{In}_{2} \mathrm{O}_{3}: \mathrm{Sn}$ prepared by the hot spray technique [76].

\subsubsection{Fluorine-Doped Tin Oxide (FTO)}

In spite of its excellent optoelectronic performances, the scarcity of indium has been regarded as a serious problem for the usage of ITO [79], thus the development of alternative TCO materials has attracted great attention. Fluorine doped tin oxide is a similarly high performing TCO material that has been successfully used in low-E glazing, such as Pilkington K-glass ${ }^{\mathrm{TM}}[80]$ and AGC $\mathrm{AO}^{\mathrm{TM}}$ series glass [81].

Back in the early 1980s, conductive F-doped tin oxide films with high optical transmission $(>80 \%)$ and infrared reflection $(\sim 70 \%$ at $2500 \mathrm{~nm})$ had been produced on glass surfaces by spray pyrolysis [82], representing FTO was a good candidate for low-E coating. Nowadays, chemical vapour deposition, especially atmospheric pressure CVD (APCVD), is the most commonly used method for the production of FTO [83]. For example, the F: $\mathrm{SnO}_{2}$ coatings on Pilkington K-glass and AGC AO series glass are all deposited by APCVD on a float glass production line. Aside from these well-established commercial products, in recent years, specific research has been conducted to further improve the optical performance of the FTO coating. Bhachu et al. reported the 1.6 at $\% \mathrm{~F}$ doped $\mathrm{SnO}_{2}$ films deposited by AACVD could show high charge carrier density $\left(5.7 \times 10^{20} \mathrm{~cm}^{-3}\right)$, visible transmittance $(\sim 80 \%)$ and reflectance in the IR range ( $80 \%$ at 2500$)$ together, which is superior to that of Pilkington-K glass $^{\mathrm{TM}}$ (TEC 8) [84].

However, the carrier concentration in Fluorine Tin Oxide cannot be further enhanced, probably due to a doping limit, to enable a shift in the plasma wavelength to the beginning range of infrared light; therefore, FTO, whilst an excellent Low-E material, is not suitable for solar control applications.

\subsubsection{Group-III Elementals Doped Zinc Oxide}

In the last decade, zinc oxide has been extensively investigated due to its large band gap, high chemical and thermal stability, low cost, no toxicity and ease of fabrication $[85,86]$ As a result, 
high carrier density based $\mathrm{ZnO}$ becomes a promising candidate for new energy efficient coatings. Group-III elements, including $\mathrm{Al}$ and $\mathrm{Ga}$, are two common $n$-type dopants for $\mathrm{ZnO}$, and they have been successfully incorporated in zinc oxide through a variety of deposition methods.

High quality $\mathrm{Al}$ or Ga doped $\mathrm{ZnO}$ films have been fabricated by CVD techniques since the early 1990s. Hu et al. first prepared Al-doped and Ga-doped ZnO from APCVD, whereby the films exhibit high carrier density (up to $8.0 \times 10^{20} \mathrm{~cm}^{-3}$ ), visible transmittance $(>80 \%)$ and infrared reflectance (up to $90 \%$ in the far infrared range) $[87,88]$. However, the precursor they used, such as diethyl zinc and dimethyl zinc, are pyrophoric and quite expensive, so few studies followed on APCVD ZnO after that. Moreover, Bhachu et al. found that the carrier concentration in $\mathrm{ZnO}$ :Al films prepared by AACVD could reach $4.35 \times 10^{20} \mathrm{~cm}^{-3}$ combined with favourable visible transmittance $(\sim 76 \%)$ and infrared reflectance (35\% at $2500 \mathrm{~nm})$, but diethyl zinc was still used as a zinc precursor [89]. Several recent studies report transparent conductive GZO films successfully produced by AACVD using low-cost zinc and gallium acetylacetonates, and the best sample could exhibit high carrier concentration $\left(4.22 \times 10^{20} \mathrm{~cm}^{-3}\right)$, visible transparency $(84.7 \%)$ and infrared reflection $(48.9 \%$ at $2500 \mathrm{~nm})$, which is close to that of Pilkington-K glass, as shown in Figure 7.

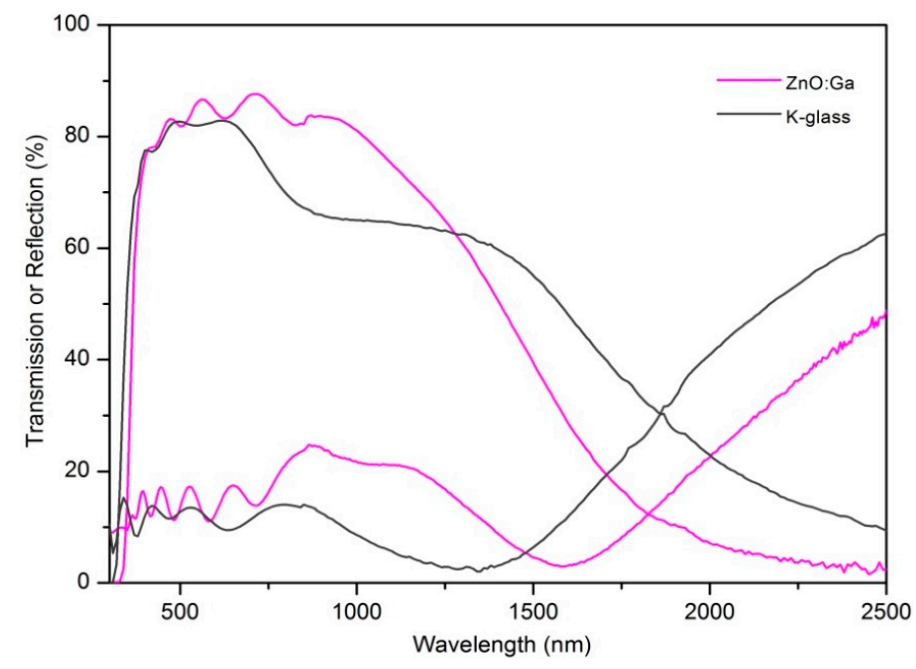

Figure 7. Optical transmission and reflection spectra of $\mathrm{ZnO}$ :Ga films grown by AACVD.

Sputtering is another widely used method to fabricate doped $\mathrm{ZnO}$ coatings on glass surfaces. The obtained film performance is often superior to that produced by CVD. Kim et al. prepared AZO films using the R.F. magnetron sputtering method, and the coatings show good optical transparency and high infrared reflection ( $70 \%$ at $2500 \mathrm{~nm}$ ) [90]. Ma et al. found that the ZnO:Ga films deposited by DC reactive magnetron sputtering could obtain a $90 \%$ visible transmittance and $72 \%$ infrared reflectance at $2500 \mathrm{~nm}$. The carrier concentration was as high as $2.5 \times 10^{21} \mathrm{~cm}^{-3}$ and the plasma wavelength $(\sim 1340 \mathrm{~nm})$ was near the beginning range of infrared light [91]. In summary, from the perspective of opto-electrical performance, $\mathrm{Al}$ or $\mathrm{Ga}$ doped $\mathrm{ZnO}$ films could meet the requirements for Low-E and solar control applications.

\subsection{Conclusion and Outlook for Energy Efficient Glazing}

Basing on the above observations, we can see that Indium Tin Oxide and Fluorine Tin Oxide have already been very successfully utilized as energy efficient coatings by the glazing industry. The carrier density in sputtered ITO coatings is easy to be tuned between $10^{20}$ and $10^{21} \mathrm{~cm}^{-3}$ to meet Low-E or solar control applications. However, the scarcity of Indium and high cost of vacuum deposition systems limit its further application. Alternatively, FTO coatings can be produced by APCVD on a float glass production line, making them popular in Low-E glazing but not for solar control window since the carrier concentration in FTO is hard to surpass $10^{21} \mathrm{~cm}^{-3}$. 
Developing new energy saving materials with a cost-effective method is the trend as well as the challenge for future glazing industry. The best candidate for new TCO material could be group-III elements doped zinc oxide. The AZO and GZO films produced by sputtering or CVD method could meet the optical requirement for Low-E coating or solar control application. However, in order to produce these $\mathrm{ZnO}$ coatings via the large-scale APCVD route, more research work is needed to develop stable and inexpensive zinc precursors. As to the novel low-cost deposition method, we believe the aerosol assisted chemical vapour deposition could be a potential choice. The main advantage of AACVD compared with other CVD methods is it provides a wider choice and availability of precursors for high quality CVD products [92]. In addition, it is a simple and potentially industrially scalable process with low maintenance and set-up costs [93,94].

\section{Solar Cell Glazing Application}

With increasing acceptance of the environmental concerns initially expressed by scientists more than 25 years ago [95] coupled with the escalating cost and demand for readily available energy, governmental policy is shifting to place more legislation on the sustainability and environmental impact of new buildings. As a result, more pressure is being placed on architects and manufacturers to design buildings, which are not only energy efficient, but incorporate their own renewable energy supply. One of the most attractive options to achieve this is to use building-integrated photovoltaics (BIPVs). Solar energy is often considered the cleanest and most abundant renewable energy option [96], and with the sun's irradiation to earth producing about 10,000 times more energy than that required for daily use by mankind it is considered by many to be the most viable option to meet demand [97].

For many years, BIPVs have been limited to single p-n junction devices such as "add-on" monocrystalline silicon solar cell panels on the roof area of buildings, and despite their reducing cost there is significant interest to develop BIPVs, which can be integrated more harmoniously into buildings without affecting the overall aesthetics. The incorporation of semi-transparent solar cells into window glazing is a particularly attractive alternative, potentially enabling visually pleasing building design in combination with solar power generation on a much larger scale. However for this solar glazing to become a truly practical and realistic alternative it must be low cost, semi-transparent, have high power conversion efficiency and be easy to manufacture [98]. Ideally solar glazing should be manufactured in-line utilising existing technologies, such as chemical vapour deposition or sputtering which are already in place within the glazing industry. In addition, transmittance must be optimised whilst maintaining substantial power generation that can offset energy demands in the building.

Currently there is a vast array of research into developing next generation materials for BIPVs that do not rely on the conventional single $\mathrm{p}-\mathrm{n}$ junction, that are called 'third-generation' photovoltaics. For solar glazing, the most successful approaches have utilised dye-sensitized solar cells (DSSCs) and organic photovoltaics (OPVs), which are particularly suitable as they meet all criteria and are made from relatively low cost materials whereby their manufacture can be easily scaled up to an industrial level $[98,99]$. However, each of these technologies have been subject of intense scrutiny in terms of their potential stability under 'real-life' conditions. As a result, there has been a wide range of variations to these technologies, in particular with the DSSC that has produced a rapidly developing area of research into emerging photovoltaic technologies that have the potential to be used in solar glazing, which will be discussed herein.

As window glazing serves a fundamental role in building architecture by visually connecting occupants to the outdoor world while protecting them from the elements, it is understandable that transparency and aesthetic appearance combined with cost-effective energy production are the main priorities in the development of solar cell glazing. This review discusses the recent developments and challenges in producing semi-transparent solar glazing for windows. 


\subsection{Dye-Sensitized Solar Cells (DSSC)}

Since its initial conception in 1991 by Gratzel and O'Regan [100], the DSSC has been a continually attractive method for converting solar light to electric power and has been the subject of many investigations [101-107]. This considerable interest into the DSSC is a result of its many advantages over traditional solar cell technologies, such as low production cost, simple fabrication methods, easy scale-up ability, architectural and environmental compatibility as well as good performance under weak/diffuse light [108]. However, the efficiency of DSSC technology is currently lower than traditional PVs, at $11.9 \%$ for those DSSCs commercially manufactured by Sharp [109] and a maximum of $12.3 \%$ for those produced at lab scale [110] and even less for semi-transparent systems (Efficiency $<2 \%$ ) that may be used in glazing. This in comparison to silicon technology where efficiencies are of the order of $26 \%$.

The DSSC typically consists of a transparent conducting electrode of fluorine-doped tin oxide (FTO) glass, which is coated, with a dye-sensitized mesoporous thin film of $\mathrm{TiO}_{2}$. A photovoltaic effect is then produced at the interface between a redox electrolyte and the thin film of $\mathrm{TiO}_{2}$ when a platinum counter electrode is added to complete the electrochemical cell [110]. For semi-transparent DSSCs it is more common for a counter electrode of glass with an FTO or ITO (Indium-doped tin oxide layer) to be used, as shown in Figure 8. (All picture credit to Bella et al.) [111].

Despite considerable research interest, concerns over the DSSCs long term chemical stability has resulted in limited practical development within industry, whereby the organic dye and redox electrolyte exhibit limited stability under real-life conditions [112]. For use in solar glazing, these issues with stability must be addressed to enable commercial viability. In particular, the liquid electrolyte which usually consists of an iodide/tri-iodide redox couple poses the problem of solvent leakage, low durability and corrosion within the DSSC [113]. In an attempt to combat these problems, many research groups have focused on substituting the liquid electrolyte for other materials, with the main alternatives being either solid or quasi-solid (QS) inorganic or organic hole-transporting materials, such as gel electrolytes prepared by ionic liquids or by the solidification of liquids [114], and polymer electrolytes [115].

It is this research interest in alternative electrolytes for DSSCs that has spawned a large area of research centred on solid-state dye sensitized solar cells (ssDSSC). These solid hole transporting materials used in ssDSSCs typically exhibit small molecular size $(\sim 2 \mathrm{~nm})$, high solubility as well as an amorphous structure that enables good impregnation of the photo anode mesopores [116]. At present, the most efficient and widely used organic hole conductors are spiro-OMeTAD (2,2',7,7'-tetranis-( $N, N$-di-p-methoxyphenyl-amine) $9,9^{\prime}$-spirobifluorene) [117] and bis-EDOT (bis-ethylenedioxythiophene) [118], with efficiencies of $6.08 \%$ and $6.1 \%$ respectively [111]. For a more detailed description and analysis of the ssDSSC and other variants of DSSC technology the reader is referred to the recent reviews by Upadhyaya et al. [119] and Hardin et al. [120].

\subsection{Organic Photovoltaics (OPVs)}

As with DSSCs, organic photovoltaics have been the subject of active research for the past 20 years, with benefits arising from their inherent low-cost and potential to be formed on flexible substrates. However, for solar glazing it is their low production costs which make them particularly favourable candidates [121]. There are several organic-based approaches that produce semi-transparent OPV devices that exhibit good electrical performance (Figure 8), whereby they are composed of organic electronic materials, and transparent electrodes based on a wide range of different materials, including conducting polymers [122-125], thin metal films [126], sputtered transparent conducting oxides of $\mathrm{LiCoO}_{2} / \mathrm{Al}$ [127], carbon nanotubes [122], graphene [128], and silver nanowires (Ag NWs) [129-133]. 

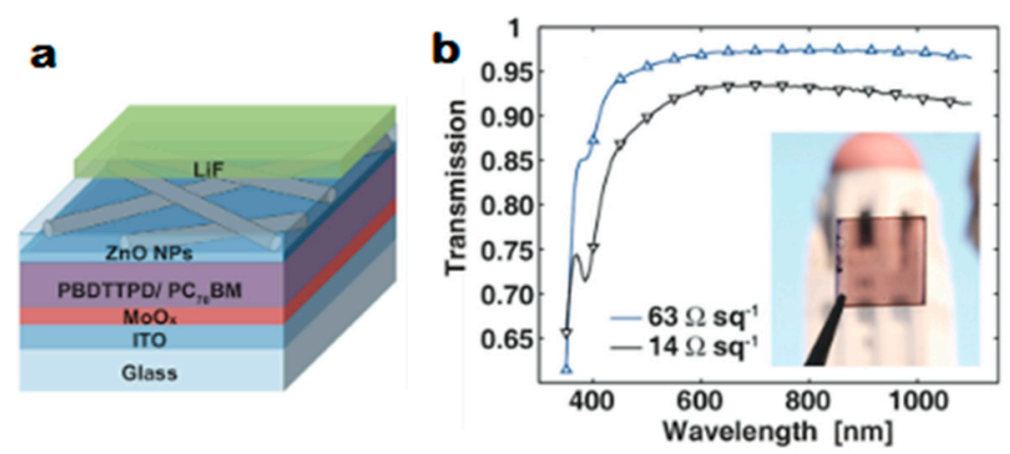

Figure 8. (a) Schematic of the semi-transparent OPV architecture. The LiF layer is partially removed in the schematic to better show the underlying layers, but covers the entire cell active area in actual devices (b) Transmission of Ag NW-ZnO NP composite electrodes with different sheet resistances. The reflection and absorption of the glass substrate has been subtracted. Inset is photograph of semi-transparent OPV [134].

Recently, a study by Beiley et al. [134], has shown the development of a semi-transparent OPV which consists of a silver nanowire (Ag NW) and zinc oxide nanoparticle ( $\mathrm{ZnO} \mathrm{NP}$ ) composite top electrode, and has a power conversion efficiency of $5.0 \%$. Additional studies have indicated that Ag NWs can be used as an efficient top electrode for semi-transparent OPV systems where P3HT:PCBM is used [129].

This Ag NW ZnO NP composite top electrode produced by Beiley et al. [134] shows great compatibility for solar glazing production, whereby it has low sheet resistance $\left(14 \Omega \cdot \mathrm{sq}^{-1}\right)$ required for large scale module manufacturing, and it is also processed in solution, making it particularly suitable for low-cost, high throughput fabrication techniques that are favoured in the glazing industry.

Commercially, semi-transparent OPVs for solar glazing have been developed by New Energy Technologies Inc. and are called SolarWindow ${ }^{\mathrm{TM}}$ coatings (New Energy Technologies Inc., Columbia, MD, USA). This technology utilises ultra-small organic solar cells that are made of natural polymers so can be dissolved into liquid for easy application including screen printing, ink-jet printing and spraying. Further details of the technology including power conversion efficiency are held back under patents, although it seems that no large scale testing has been conducted as yet [135].

However, as with DSSCs, the current performance of OPVs is much lower than traditional solar cells, as can be seen in Figure 9 which shows the NREL (National Renewable Energy Laboratory) 'Best Research-Cell Efficiencies' whereby OPVs are peaking at around the $11 \%$ mark, which is less than half the efficiency of their crystalline silicon counterparts at $27.6 \%$ [136]. In addition, OPVs have historically had a poor long-term durability which has limited their applications in solar glazing thus far, however they have now been shown to withstand many thousands of hours under favourable circumstances [137].

Furthermore, semi-transparent OPVs based on the most commonly used active material blends of poly(3-hexylthiophene) (P3HT) and [6,6]-phenyl-C61-butyric acid methyl ester (PCBM) demonstrate relatively low efficiency, and their limited spectral absorption results in a strong colour bias of the transmitted light [138]. Although coloured windows are useful for decorative purposes, for large-scale use more neutral colours are preferred. 
Best Research-Cell Efficiencies

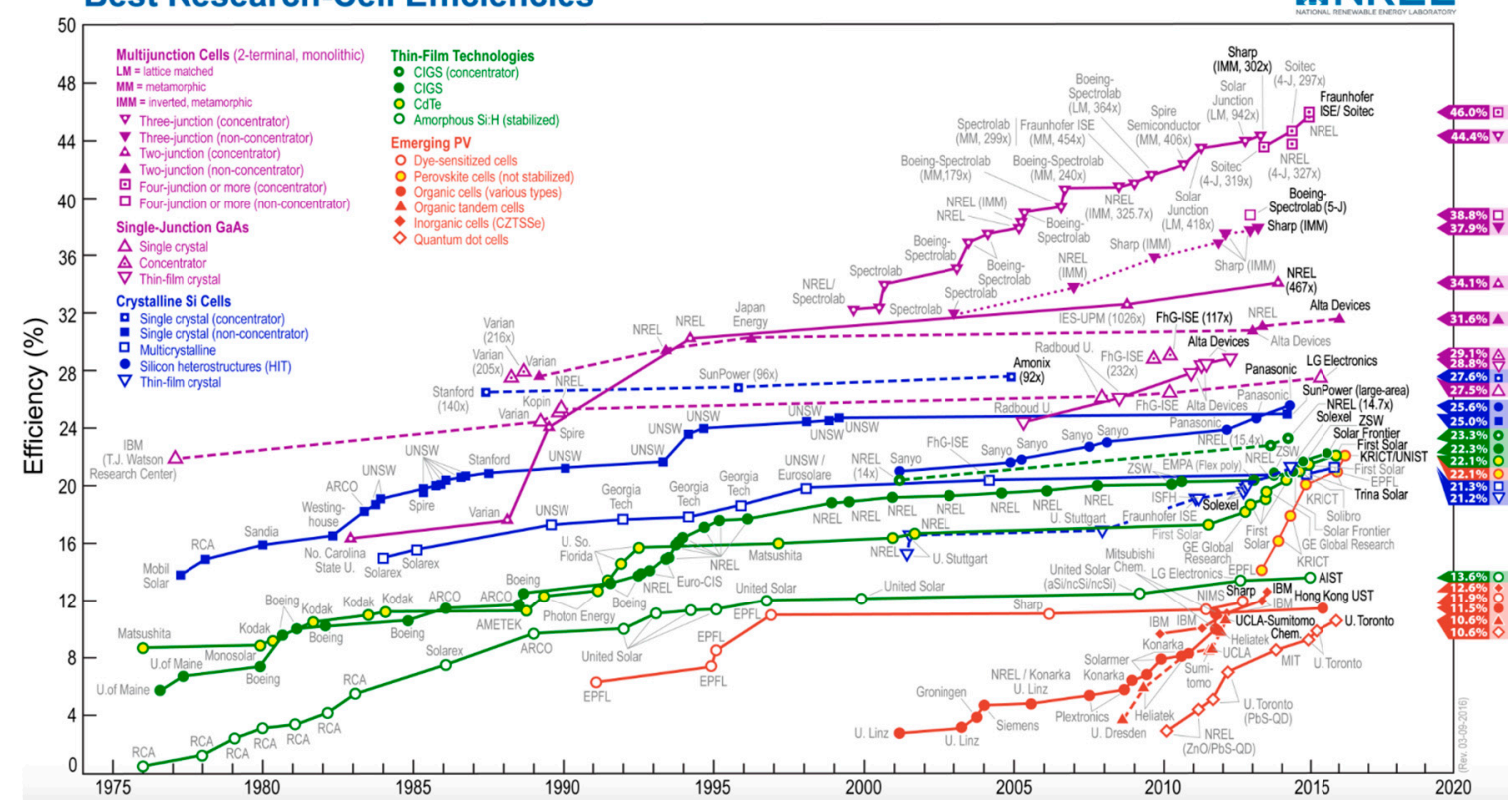

Figure 9. NREL Chart showing best research-cell efficiencies [136].

\subsection{Recent Emerging Photovoltaics (PV)}

This broad research into DSSC technology has spawned a wide range of DSSC variations, which have been designed with specific targeted improvements in mind. The schematic shown in Figure 10 taken from the perspective review by Snaith [139] shows the historical evolution of the DSSC into ssDSSC technology, as well as the more recent developments into perovskite MSSCs (Mesosuperstructured solar cells) and an indication to future directions in research.

These semi-transparent solar cells based on perovskites have recently emerged as a potential contender for efficient solar glazing in windows due to their rapid increase in power conversion efficiency, whereby in just four years the perovskite cells have exhibited enhanced efficiency from $3.8 \%$ in 2009 to $17.9 \%$ in early 2015, with expectations to reach even higher efficiencies soon [94,132,140,141]. This demonstrates that understanding of photovoltaic materials has grown considerably since the development of traditional single-crystal solar cells, whose efficiency grew by less than $50 \%$ during their first five years of development (See Figure 10) [142].

Perovskite semi-transparent photovoltaics use a thin layer of semiconducting perovskite, which can be produced, at low temperatures using inexpensive and abundant materials. However, despite their promising efficiencies, these photovoltaic cells suffer with the same aesthetic undesirability which is typical of conventional semiconductors in that they have an inherent red-brown tint [143]. In addition, significant research is required in order to establish the long-term stability of these PV materials, as all efficiencies quoted are for small-scale lab-based modules, and currently, to the author's knowledge, there has been no such investigation into their potential stability to withstand 'real-life' conditions on a larger scale, and no expected lifetime. For this technology to be truly viable as solar glazing considerations into the desirability of tinted solar glazing as well as the long-term durability will have to be addressed, however these new materials show great promise due to their rapid increase in efficiency over recent years. 


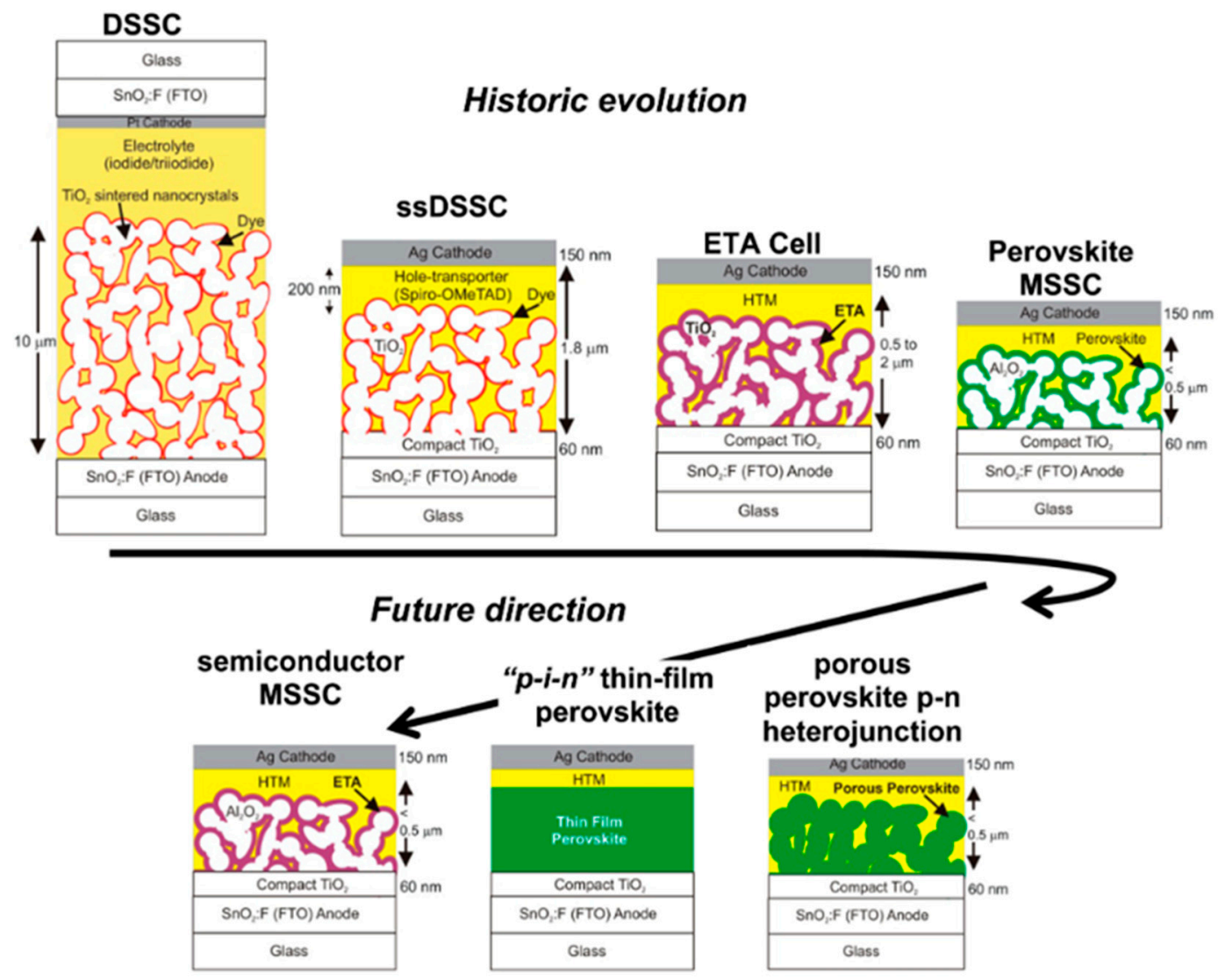

Figure 10. Historic evolution of the solar cell technology, starting from the electrolyte-based mesoscopic DSSC, the ssDSSC where the electrolyte is replaced with an organic p-type hole conductor, the ETA cell where the dye is replaced with an ETA semiconductor layer, to the MSSC, where the ETA is replaced with a perovskite absorber and the n-type $\mathrm{TiO}_{2}$ is replaced with a porous insulating scaffold. Three likely future directions for the perovskite technology are indicated: (i) porous perovskite distributed p-n heterojunction solar cells, where the $\mathrm{Al}_{2} \mathrm{O}_{3}$ is removed but the perovskite is directly structured to give a porous film subsequently filled in with a charge conductor; (ii) thin-film $\mathrm{p}-\mathrm{i}-\mathrm{n}$ perovskite solar cells where no porosity is required and the device takes on the structure of an intrinsic, or at least ambipolar, thin perovskite film sandwiched between $\mathrm{p}$ - and n-type charge-extracting contacts; or (iii) semiconductor MSSCs, where any solution-processed semiconductor, such as SbS, can be structured by the porous scaffold to deliver a MSSC [142].

\subsection{Conclusion and Outlook for Solar Cell Glazing}

In comparison with other BIPV products that have reached the commercialisation stage, solar glazing materials can be considered as still in their infancy. A state-of-the-art review by Jelle et al. [144] on BIPV products includes several appendices on current BIPV modules available on the market, including those for solar glazing applications to which the reader is referred.

As one of the main criteria of solar glazing (in addition to good transparency) is to enable a sufficient energy offset for the entire building, studies have shown that buildings which incorporate solar glazing technology can exhibit overall electricity consumption reductions of up to $55 \%$ compared to standard single glazed windows $[7,140,141]$. As solar glazing BIPVs enable sustainable generation of electricity, reduction in solar heat gain for the implementation of day lighting schemes that save lighting energy consumption and heating requirements within a building, they can be described as a development in building architecture that can be installed in order to offset overall construction and building running costs [145]. 
However, the main factor holding back the integration of solar glazing into buildings on a wider scale is a combination of the initial start-up cost and resulting efficiency. The majority of solar modules currently available commercially use a technology which involves spraying a thin coating of silicon nanoparticles onto the window which then works as a solar cell, and can be customised to suit efficiency needs from $5 \%$ to $22 \%$ [14]. These materials are still relatively expensive in comparison to the solar glazing technologies discussed within this review, and the efficiency is variable depending on the level of transparency desired. To date there is very limited availability to buy the cheaper modules based on thin film or PV technologies such as DSSC, OPVs or perovskites commercially. This is because despite their promising efficiencies and good visible transparency, these technologies are still too juvenile to demonstrate their stability over a longer time period under real-life conditions. Aside from the fine balance of enhancing transparency without diminishing power conversion, enhancing stability is the main issue to be addressed to enable the development of a solar glazing product based on these technologies that is suitable for market. Future research into the technologies discussed here will aim to target this issue of stability, as well as to increase understanding and development of the materials used within these devices.

Despite the challenges facing solar glazing research, increasing commercial interest into emerging semi-transparent photovoltaics is continually driving the sector forward. Building manufacturers and architects are beginning to use transparent BIPV modules such as that shown in Figure 11, with acceptable aesthetic results, and the demand and desirability for solar glazing is growing. If the issues regarding stability can be properly addressed, then it seems highly likely that solar glazing will be the next to follow.

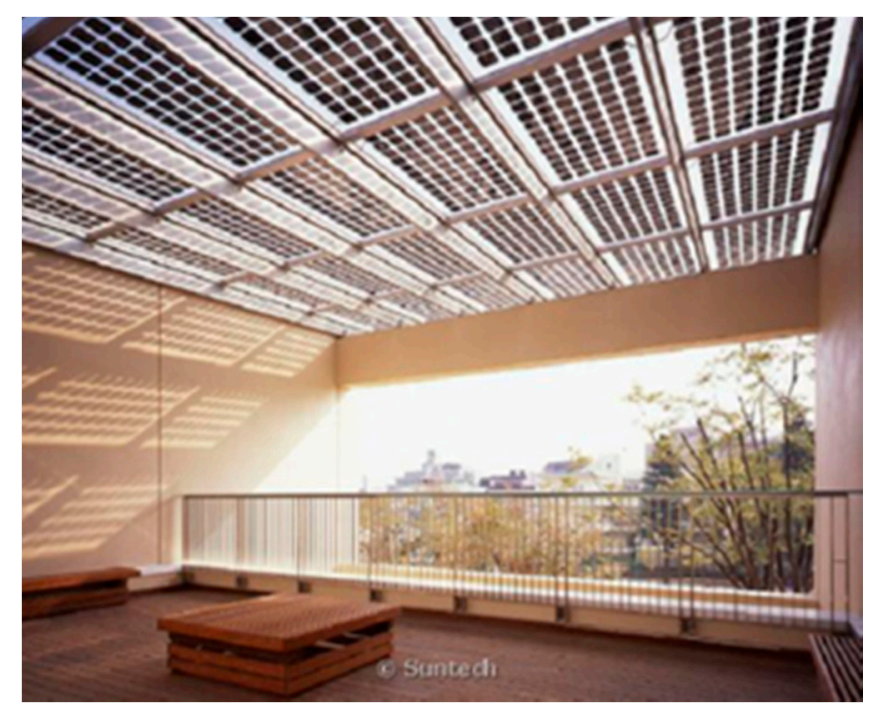

Figure 11. Glass ceiling with transparent BIPV modules [145].

\section{Thermochromic Glazing}

Thermochromic (TC) glazing can potentially help in reducing the energy demand of buildings that seems to be ever increasing [146,147]. Thermochromic glazing changes its optical properties in a dynamic manner in response to eternal temperature [148].

Glazing's based on thermochromic coatings are designed to intelligently control the amount of light and heat (mainly in the near infra-red region) upon a change in the temperature. A number of transition metal compounds, including $\mathrm{Fe}_{3} \mathrm{O}_{4}, \mathrm{FeSi}_{2}, \mathrm{NbO}_{2}, \mathrm{NiS}, \mathrm{Ti}_{2} \mathrm{O}_{3}, \mathrm{Ti}_{4} \mathrm{O}_{7}, \mathrm{Ti}_{5} \mathrm{O}, \mathrm{V}_{2} \mathrm{O}_{3}$ and $\mathrm{VO}_{2}$, have been found to have thermochromic properties. Even though they offer good transmittance modulation in the visible region, they generally do not offer proper switching in the near IR range of the spectrum or have transitions at suitable temperatures [149]. Among them, vanadium dioxide $\left(\mathrm{VO}_{2}\right)$ 
based thin films have been emerged as suitable candidates for TC intelligent glazing applications since they exhibit a sharp transition temperature $\left(\mathrm{T}_{\mathrm{C}}\right)$ close to room temperature $\left(68^{\circ} \mathrm{C}\right)$ [150].

\subsection{Thermochromic $\mathrm{VO}_{2}$}

First noticed in 1959 by Morin [151], a single pure $\mathrm{VO}_{2}$ crystal exhibits a semiconductor to metal transition from low temperature monoclinic phase $\left(\mathrm{VO}_{2} \mathrm{M}\right)$ to high temperature rutile phase $\left(\mathrm{VO}_{2} \mathrm{R}\right)$. At the temperatures below $T_{c}$, the material is transparent in both the infra-red (IR) and visible part of the spectrum, therefore it allows solar radiation to pass through the window by maximising the heating effect of sunlight and minimising black body radiation within the building [152]. On the other hand, at temperatures above $T_{\mathcal{c}}$ these glazing's are transparent in the visible but become reflective in the IR part of the spectrum [153] (Figure 12) [62]. This characteristic prevents the thermal part of solar radiation from heating the building interior. In other words, in the hot climates $\mathrm{VO}_{2}$ glazing can block much of the incident near infra-red (NIR) solar radiation; thus reducing solar heating of the inside of the building and reducing cooling requirements $[154,155]$. For cooler weather conditions on the other hand, this types of glazing allows the light in the NIR region to pass through the coating thus warming the building and reducing the need for additional heating [156]. As such thermochromic materials allow for a greater use of natural light, which is highly desirable as internal lighting, they make a further contribution towards reducing the building energy demand [11].

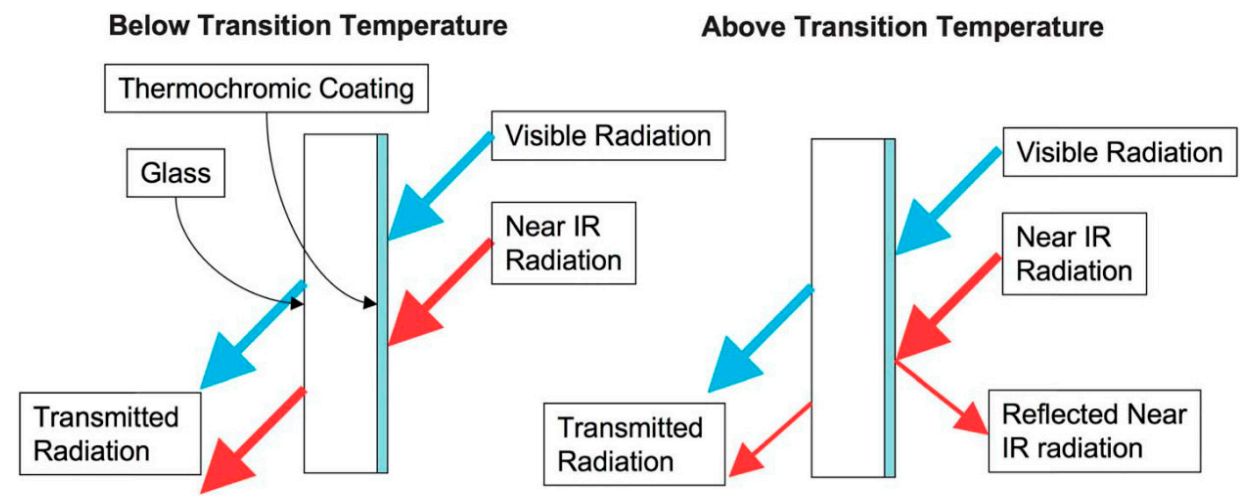

Figure 12. Schematic of thermochromic behaviour of thermochromic vanadium dioxide glazing [62].

Thermochromic properties of the films are characterised by the critical transition temperature $\left(T_{c}\right)$, change in the percentage of transmittance $(\Delta T)$ and reflectance $(\Delta R)$ values, as shown in Equations (1) and (2) where $T_{\text {coloured }}$ and $T_{\text {transparent }}$ denotes transmittance changes and $R_{\text {coloured }}$ and $R_{\text {transparent }}$ denotes reflectance modulations between coloured and transparent states, respectively. Wavelength integrated luminous and solar transmittance values are expressed in Equation (3), where $\tau$ indicates the thickness of $\mathrm{VO}_{2}$ thin film, $\varphi$ is the spectral sensitivity of the light adapted eye and $\lambda$ the wavelength of light $[156,157]$. These integrated values allow an assessment for visual and energy-related performance of the thermochromic thin films.

$$
\begin{aligned}
\Delta T(\%) & =T_{\text {coloured }}-T_{\text {transparent }} \\
\Delta R(\%) & =R_{\text {coloured }}-R_{\text {transparent }} \\
T_{\text {lum }, \text { sol }}(\tau) & =\frac{\int d \lambda \varphi_{\text {lum }, \text { sol }}(\lambda) T(\lambda, \tau)}{\int d \lambda \varphi_{\text {lum }, \text { sol }}(\lambda)}
\end{aligned}
$$

In all glazing systems visible transmittance of at least $60 \%$ is desirable so as to allow enough light to the building. There ought be a large decrease in the transmittance (Figure 13a) and a large increase in the reflectance (Figure 13b) in the near infra-red region of the solar spectrum (Figure 4) [158]. 
An idealized optical response shown by a thermochromic $\mathrm{VO}_{2}$ film, below and above its critical transition temperature is summarized in the Table 1.

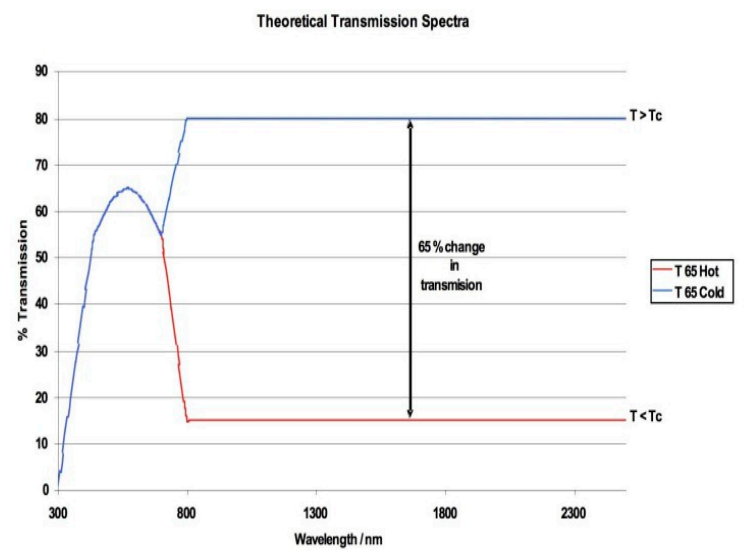

(a)

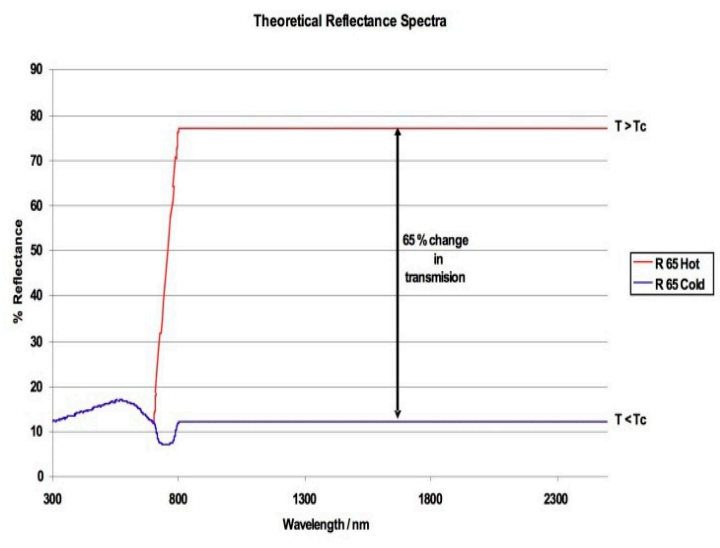

(b)

Figure 13. Idealized UV-Vis spectra for a thermochromic $\mathrm{VO}_{2}$ glazing, with (a) transmittance and (b) reflectance modulations [157].

Table 1. Optical response of a thermochromic $\mathrm{VO}_{2}$ film below and above its critical transition temperature $\left(T_{c}\right)$.

\begin{tabular}{ccccc}
\hline \multirow{2}{*}{ Condition } & \multicolumn{3}{c}{ Temperature } \\
\cline { 2 - 5 } Cold $\left(T<T_{c}\right)$ & \multicolumn{2}{c}{ Hot $\left(T>T_{c}\right)$} \\
\hline Structure & Monoclinic, semiconducting & \multicolumn{2}{c}{ Rutile, metallic } \\
Wavelength & Visible $(\%)$ & Near IR $(\%)$ & Visible $(\%)$ & Near IR $(\%)$ \\
Transmittance $(\mathrm{T})$ & 65 & 80 & 65 & 15 \\
Reflectance $(\mathrm{R})$ & 17 & 12 & 17 & 77 \\
\hline
\end{tabular}

\subsection{Challenges Related to Thermochromic $\mathrm{VO}_{2}$ Glazing}

The thin films of $\mathrm{VO}_{2}$ have been the subject of significant research efforts and so many reports show that $\mathrm{VO}_{2}$ exhibits promising characteristics of thermochromic transition for intelligent glazing applications. Nevertheless, practical implementation of thermochromic $\mathrm{VO}_{2}$ films as architectural windows has been hampered by the following performance deficiencies:

1. Principally, thermochromic transition temperature of $\mathrm{VO}_{2}$ is $68^{\circ} \mathrm{C}$. However, a thermochromic window with an energy-efficient benefit should have an ideal transition temperature between 20 and $25^{\circ} \mathrm{C}$ with a high visible transmittance and solar modulation ability. Since this critical temperature $\left(T_{c}\right)$ for is too high to be effective to be utilized, efforts need to be made to reduce it to near room temperature [158].

2. The second difficulty associated with the $\mathrm{VO}_{2}$ films is the thermochromic efficiency of the transition (Figure 14). In order to mitigate the solar heat gain efficiently, the thermochromic transition should take place quickly; it means that the gradient of the thermochromic transition hysteresis should be steep and that the hysteresis loop width should be as narrow as possible [157]. A smaller hysteresis width is also preferred to acquire larger response to temperature and a higher efficiency [159].

3. A further undesirable aspect which has to be improved of $\mathrm{VO}_{2}$ coating is the yellow colour of vanadium dioxide films that disturbs the aesthetic appearance of the windows (Figure 15) and makes the films difficult to market [155]. As a result of this colouration, the luminous transmittance values of the $\mathrm{VO}_{2}$ films are often lower than desired (around $30 \%-40 \%$ ) which is a significant obstacle to employ these films for windows coatings applications. 


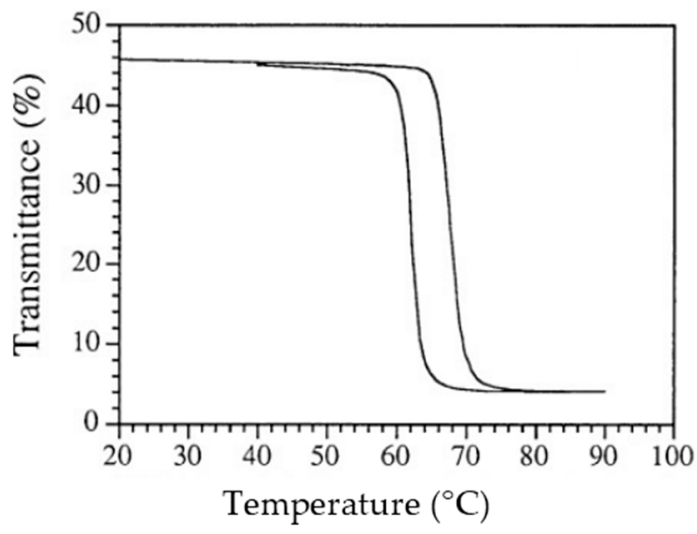

Figure 14. An example of hysteresis curve observed for a thermochromic $\mathrm{VO}_{2}$ film [160].

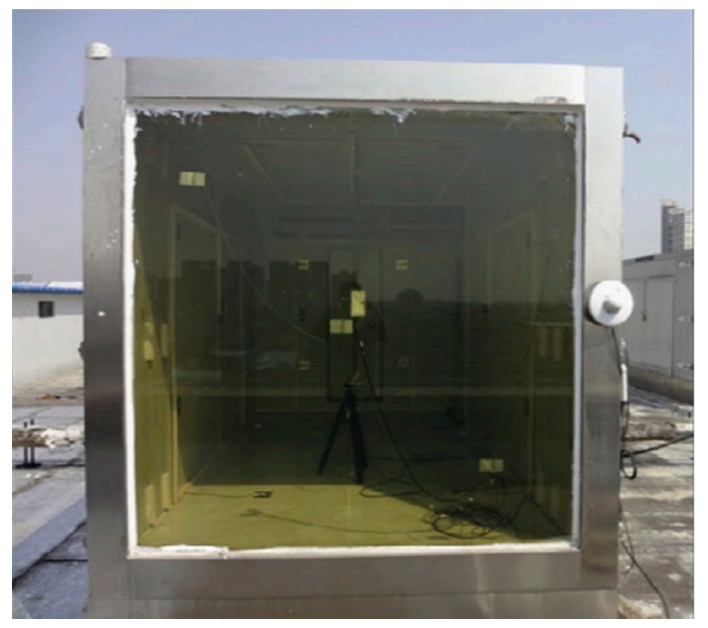

(a)

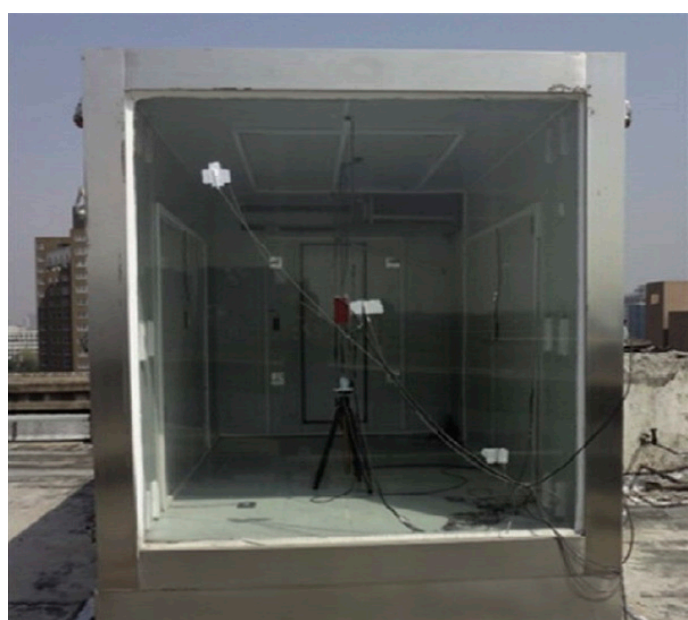

(b)

Figure 15. Example windows with thermochromic $\mathrm{VO}_{2}$ glazing's (a) and ordinary (b) [155].

The production of $\mathrm{VO}_{2}$ films with high visible transmittance, efficient optical NIR transition and reflection modulation properties, lower $T_{\mathcal{c}}$ values, along with narrower and sharper hysteresis loop widths, remains a worthy pursuit as a significant energy benefit can be derived from such materials [149].

In order to achieve optimal thermochromic performance of the $\mathrm{VO}_{2}$ films, several strategies have been employed, including the implementation of a variety of deposition methods, the preparation of multi-layered films, and the introduction of dopants.

\subsubsection{Reducing the Transition Temperature}

The transition temperature of pure $\mathrm{VO}_{2}$ is $68{ }^{\circ} \mathrm{C}$, this should be ideally as close to room temperature as possible for optimal thermochromic control in buildings. The majority of previous investigations have looked at the doping the films with high valence transition metal ions. This causes a reduction in $T_{\mathcal{C}}$ to lower values as the metal dopant causes a partial disruption to the crystal structure, effectively lowering the energy required for the phase transition [150]. Tungsten has been found to be the most efficient dopant, lowering $T_{\mathcal{C}}$ by $7{ }^{\circ} \mathrm{C}$ per at $\%$ [160], $19{ }^{\circ} \mathrm{C}$ per at $\%, 20{ }^{\circ} \mathrm{C}$ per 2 at $\%$ [161], and by $23{ }^{\circ} \mathrm{C}$ per at $\% \mathrm{~W}$ [162]. Molybdenum doping has also been explored and found to decrease $T_{\mathcal{C}}$ by $3{ }^{\circ} \mathrm{C}$ [152] and by $15^{\circ} \mathrm{C}$ [163] per at \% doping. Doping with $3 \mathrm{~mol} \%$ Mo lowered $T_{C}$ to $42{ }^{\circ} \mathrm{C}$ [164]. Niobium has also been investigated, but it was found to be less effective than tungsten. The $T_{c}$ of the films was typically decreased by $2{ }^{\circ} \mathrm{C}$ per at \% doping [164], by $13{ }^{\circ} \mathrm{C}$ per $0.4 \%$ at [165] and by 
$15^{\circ} \mathrm{C}$ per 2 at \% $\mathrm{Nb}$ doping [166]. Other dopants explored include magnesium [167] and cerium [168] which decreased $T_{\mathcal{c}}$ by $3{ }^{\circ} \mathrm{C}$ and $4.5^{\circ} \mathrm{C}$, respectively per at $\%$ doping each. Fluorine has also been incorporated, 3 at $\%$ reduced $T_{\mathcal{C}}$ to $35^{\circ} \mathrm{C}$ [169].

It has also been shown that a reduction in the crystallite size causes strain and lowers $T_{c}[170]$; nanostructured $\mathrm{VO}_{2}$ films of great interest for this reason. Warwick et al. [171] used electric field assisted chemical vapour deposition to deposit $\mathrm{VO}_{2}$ films, and observed that increasing the field strength reduced the average crystallite size, leading to a complex surface morphology and a lower $T_{c}$. A significantly low transition temperature of $29^{\circ} \mathrm{C}$ has been obtained by Chen et al. [172] who produced nanostructured $\mathrm{VO}_{2}$ films with average crystallite sizes between 20 and $50 \mathrm{~nm}$.

\subsubsection{Improving Thermochromic Efficiency}

The optimum thermochromic performance of $\mathrm{VO}_{2}$ films can only be realised by minimising transition hysteresis loop width. This characterized by analysing the speed and temperature range at which the thermochromic material can transfer between the rutile (hot) and monoclinic (cold) states. Some modelling studies have been done to investigate the extent of energy saving potential of the $\mathrm{VO}_{2}$ based thin films. These studies revealed that, a greater energy saving potential can be achieved by obtaining a narrow hysteresis loop width $\left(2-3^{\circ} \mathrm{C}\right)$ or the sharpest possible hysteresis gradient [157]. For a warm Mediterranean climate; a low transition temperature along with a sharp hysteresis gradient has been calculated to reduce the energy demand of a building by up to $51 \%$ compared to a standard glazing unit [10].

Numerous studies indicate that, the thermochromic efficiency of vanadium dioxide is dependent on a large number of different parameters, such as substrate temperature [173], annealing temperature [170-173], microstructure $[155,174,175]$ and surface morphology [170,174,176-179]. The situation is further complicated as doping with high valency metals also impacts upon the thermochromic efficiency, usually in a detrimental manner [179-183]. The use of polymer templates and surfactants has also been shown to change the surface microstructure and thus the thermochromic efficiency $[176,184]$. In some cases $\mathrm{VO}_{2}$ films that consisted of nanoparticles have been found to result in wider hysteresis widths $\left(10-20^{\circ} \mathrm{C}\right)$, although they tended to have lower critical transition temperatures $\left(\sim 40^{\circ} \mathrm{C}\right)$ [150], it has been suggested that the hysteresis width is inversely proportional to the average crystallite and grain sizes of the materials $[185,186]$ however, this is not found to be the case in all studies [163].

\subsubsection{Improving the Aesthetics of Thermochromic Films}

A visible transparency in excess of $60 \%$ is highly desirable with modern fenestration. Typically, thin films of vanadium dioxide with the optimal transition properties have a maximum visible transmission in the region of 50\%; therefore, several methods of addressing this problem have been attempted. So far, the main techniques used for this purpose were regulation of film thickness [166-188], mixtures or composites [189,190] the deposition of antireflection layers [189] and doping $[153,159,191]$.

Previous studies have shown that either Mg [167] or F [192,193] doping can lead to a visible transmittance increase of the $\mathrm{VO}_{2}$ films in greater than $10 \%$. However fluorine doping is not favourable for smart windows glazing applications, as it is known to cause poor transition behaviour, this has been attributed to a strong distortion of the host lattice caused by the anion size [161]. Magnesium, doping on the other hand, resulted in widening the fundamental band gap [191] and improved luminous transmittance $\left(T_{\text {lum }}\right)$ of the $\mathrm{VO}_{2}$ films (to ca. 51\%) [167]. Further attempts to improve the film aesthetics have been attempted with the introduction of gold nanoparticles into the vanadium dioxide film matrix, lead to a significant change in film colour due to surface plasmon resonance of the gold nanoparticles [194-196]. In addition to the use of single dopants, co doping approaches have also been tried. Magnesium and tungsten co-doped $\mathrm{VO}_{2}$ films increased the $T_{\text {lum }}$ to ca. $80 \%$ however, the doping had a deleterious effect on the thermochromic efficiency of the transition [193]. 
Another effective method to increase $T_{\text {lum }}$ of the $\mathrm{VO}_{2}$ films is to use multi-layered structures by utilising high refractive-index dielectric top or under layers [194]. In the last few decades, substantial efforts have been reported to fabricate thermochromic $\mathrm{VO}_{2}$ coatings with very thin layer of such an anti-reflection coating. This has generally served to improve luminous transmittances $\left(T_{\text {lum }}\right)$ of the $\mathrm{VO}_{2}$ films, without disturbing the existing thermochromic properties. Lee and Cho $[195,196]$ prepared $\mathrm{SiO}_{2}$ antireflection coatings which exhibited an increase in the $T_{\text {lum }}$ values from ca. $40 \%$ to $50 \%-55 \%$ at $650 \mathrm{~nm}$ with $100 \mathrm{~nm}$ anti reflection coating. $\mathrm{ZrO}_{2}$ over layer anti reflection coatings have also been used, where a $T_{l u m}$ of $55 \%$ was obtained [197]. Particularly good properties have been obtained by multilayer films consisting of $\mathrm{TiO}_{2}$ and $\mathrm{VO}_{2}$; Tazawa et al. [198] demonstrate that in addition to improving the visible light transparency of the films, production of $\mathrm{TiO}_{2}$ anti reflection layers can also offer multifunctional properties, combining thermochromic response with self-cleaning properties. Before addition of $\mathrm{TiO}_{2}$ over layers, $\mathrm{VO}_{2}$ films exhibited $T_{\text {lum }}$ values of around $30 \%$. $\mathrm{TiO}_{2}(40 \mathrm{~nm})$ on $\mathrm{VO}_{2}(50 \mathrm{~nm})$ increased $T_{\text {lum }}$ to $49 \%$ [198]. The same group later prepared double layered anti reflection coatings of $\mathrm{TiO}_{2}(25 \mathrm{~nm}) / \mathrm{VO}_{2}(50 \mathrm{~nm}) / \mathrm{TiO}_{2}(25 \mathrm{~nm})$ which exhibited an enhanced $T_{\text {lum }}$ of $57.6 \%$. Chen et al. [199] later reported higher $T_{\text {lum }}$ of $61.5 \%$. The durability of the $\mathrm{VO}_{2}$ films has also been improved by the addition of an $\mathrm{Al}_{2} \mathrm{O}_{3}$ over layer which was shown to provide protection against heat $\left(300^{\circ} \mathrm{C}\right.$ for one day) and relative humidity of $95 \%$ [200].

\subsubsection{Recent Advances in Thermochromic Glazing}

Recent work has further explored the use of $\mathrm{Mg}$ doping in thermochromic vanadium dioxide on low emissivity substrates. The incorporation of magnesium was found to enhance the films visible transmittance and to help reduce the thermochromic transmission temperature to $49.2{ }^{\circ} \mathrm{C}$ [201]. Increasingly $\mathrm{VO}_{2}$ films are being combined with other functional layers as a way of adding multi-functionality. Miller et al. have recently demonstrated the use of an $\mathrm{ITO} / \mathrm{VO}_{2} / \mathrm{TiO}_{2}$ stack. The layers gave low-emissivity, thermochromic and anti-reflection functionality. The authors were able to demonstrate that such a stack retained thermochromic possibilities, although these were some way from the ideal, indicating further work needs to be done to optimise the system [202]. The investigation of periodic porous structures is a very recent development in thermochromic thin films. This involves templating the film growth with silica spheres that are then etched or burnt away post film growth. By varying the growth time a variety of structures can be deposited ranging from nanonet like structures to inverse opal arrangements [203,204].

The use of bioinspired structures, such as moth eye type structures, has demonstrated that visible light transmittance can be dramatically increased to in excess of $75 \%$ whilst retaining reasonable thermochromic performance $[205,206]$. There has been further work in the area of nanothermochromics and the use of nanoparticle systems. These show promise as routes to lowering the thermochromic transition temperature without the deleterious effect of metal doping [207]. Work by Greek researchers has demonstrated that amorphous $\mathrm{VO}_{2}$ still exhibits thermochromic properties although it is noted that the transition width and gradient of such films are wide and sloping and therefore suboptimal for use in energy saving systems [208].

\subsection{Conclusion and Outlook for Thermochromic Glazing}

Vanadium (IV) oxide is the most studied thermochromic material due to its transition temperature being the closest to room temperature, and as such exhibits the greatest potential for application in thermochromic devices and "intelligent" glazing systems. However, significant challenges must be overcome in order to manufacture a commercial window coating include factors such as colour, scale-up, and thermal cycling.

A transition temperature of $68^{\circ} \mathrm{C}$ is still too high, applications such as "intelligent" thermochromic glass require switching temperatures between 18 and $25^{\circ} \mathrm{C}$. The precise switching temperature can be tuned, by doping the material. Tungsten (VI) has been found to be the most promising reducing the transition temperature by $22{ }^{\circ} \mathrm{C}$ per atomic \% incorporated. 
Incorporating gold nanoparticles into the films via a hybrid aerosol-assisted and atmospheric pressure CVD technique shows potential to improve the colour of the $\mathrm{VO}_{2}$ films, compared to the tungsten doped films, however, the cost of gold is likely to be an issue. Fluorine or magnesium doping or the use of optical stacks may well prove to be the optimal way forward.

The energy-saving performance of the films is predominantly controlled by the thermochromic switching temperature and number of hours the film spends in the hot state. Simulation results show that, in warmer climates, a lower transition temperature leads to energy savings, thus reduction of the $T_{c}$ to around room temperature will lead to further energy-saving behaviour.

A possible drawback to this new technology is that availability of the resources needed in order to produce these coatings. One must not forget that this will be a large-scale production of new technology and issues such as accessibility of the raw materials needed should be considered. Nevertheless, the current energy situation and future issues, such as population growth and increasing standards of living, will inevitably demand a safe and affordable solution to the shortage of fossil fuels and environmental effects such as global warming. We believe that thermochromic technology and thin film materials can play an important role in finding the appropriate solution.

\section{Building Integration Issues}

The aesthetics of glazing is very important to its success as a commercial product and has been one of the stumbling blocks for various systems such as electrochromic nickel oxide or thermochromic vanadium dioxide coatings. The films discussed here also have several issues in the area of aesthetics.

The overall levels of visible transmission for DSSC type glazing and thermochromic vanadium dioxide lays in the range $0.45-0.60$, somewhat less than what is considered in industry to be required for a saleable product. For glazing products, the general consensus view is that higher visible transmission is desirable in order to reduce lighting loads and improve aesthetics, although there is a trade-off between higher costs for cooling or heating and visible light transmission. Of course one must question what is the point of having a window if it does not allow light through? However, we must ask the question, how much light is enough for a modern functional building? Is something that is subjective and highly dependent on the climate, building position and indeed position within a building itself. We have not attempted to answer that question here but we do suggest that a reduction in transmission may well be worth it in terms of improved energy performance.

Colouration is also an issue; thermochromic vanadium dioxide thin films are a yellow brown colour that it is thought the majority of people would not find aesthetically pleasing. We have outlined several strategies that can address this, although these all add additional complexity and cost into the coatings manufacture.

For DSSC type-glazing integration is somewhat more complicated. The other technologies discussed in this review are passive technologies that can be installed in a standard glazing unit and left to perform. DSSC's are more complicated requiring additional wiring and components to effectively integrate them into the building. There are further issues with DSSC's that relate to sealant failure or the electrolyte drying out, both of which would severely hamper the useful working lifetime of the unit.

The key advantage of the self-cleaning, thermochromic and transparent conducting oxide based thin film technologies presented here is that they are produced by atmospheric pressure chemical vapour deposition. This fabrication method can be (and is) incorporated directly into the float glass manufacture process. It allows for on line production of the films with no off line processing steps required. Atmospheric pressure chemical vapour deposition is significantly cheaper than physical vapour deposition methodologies as no expensive vacuum equipment is required. The size of glass that can be coated is limited by the width of the float glass line rather than the size of the vacuum chamber. Additionally, films produced by atmospheric pressure chemical vapour deposition are generally more adherent than those produced from physical vapour deposition methods and will therefore have longer lifetimes. As an example of the benefit of such coating systems consider body 
tinted absorbing glass, which is produced by adding additional materials into the glass melt that acts as a tint in the final product. This requires careful control of the glass melt in order to obtain consistent and even colouration, it can take up to $100 \mathrm{~h}$ before the glass melt has reached an equilibrium state and colouration is consistent. As float glass lines typically produce $800 \mathrm{~m}$ of glass an hour, an effective down time of $100 \mathrm{~h}$ means the loss of $80 \mathrm{~km}$ of glass. Although some of this wastage will be reintroduced into future glass melts this is still a huge amount of loss. Producing absorbing type glasses by applying a coating using atmospheric pressure chemical vapour deposition is therefore highly desirable from an efficiency perspective.

\section{Conclusions}

This review has discussed the technology of glazing integrated photovoltaics, solar- control Low-E, thermochromic and self-cleaning/anti-pollution materials for functional applications in buildings. Of all these technologies, solar-control and Low-E materials are the most established. These are materials based on spectral selectivity, however angularly selective materials propose the need for further research and development. Solar-control and Low-E materials are suitable for use as smart windows in climates, which are constant. However, these materials typically contain substantial quantities of indium, an element that is in short supply and as such very costly. The latest transparent conducting oxide research presented in Section 3 demonstrates that new materials such as aluminium doped zinc oxide can be a viable replacement for the traditional indium containing materials. In those climates that vary, there is a greater need for chromogenic materials (Section 5). At present the most research has been carried out on chromogenic materials whose optical properties change according to temperature (thermochromic), external voltage (electrochromic) and radiation (photochromic). Currently, thin films have been used in many applications; however, bulk materials such as photochromic glasses and polymers, thermochromic polymers and polymer based cloud gels offer other possibilities, although perhaps less desirable as these systems tend to be more complex in nature. These chromogenic windows offer the possibility of combining comfort for the occupants of the building with the growing need of energy efficiency. Photochromic thin films also pose as a possible contender for 'smart windows' as these work in a similar way to electrochromic device however an external voltage is not required. Radiation is used to change the colour of these films and set about photochromic properties within them. The most promising thermochromic materials for window glazing is vanadium (IV) oxide, due to it relativity low transition temperature of $68^{\circ} \mathrm{C}$, however this is still not low enough for it to be actually used on larger scale. The introduction of some particular dopants does in fact lower the $T_{c}$ however, there are still challenges concerning the aesthetic appearance of these films to overcome.

Glazing integrated photovoltaics based on dye-sensitized solar cells (Section 4) are in a relatively early stage of development. They however offer great potential for reducing energy demand in buildings through the absorption of solar radiation as well as generating usable energy. They also offer the potential of a variety of different colours depending on the dye used, thus affording designers and architects greater choice for their works.

Self-cleaning/anti-pollution coatings (Section 2) have been known for some time but have only recently become a saleable product. Further work remains to be completed to optimise these materials for use in destroying dangerous airborne urban pollutants such as nitrogen dioxide and volatile organic compounds. Efforts are also underway to allow these materials to be used inside buildings.

One potential drawback with regards to these new technologies is that availability of the resources needed in order to produce these coatings. One must not forget that this will be large-scale production of new technology and issues such as accessibility of the raw materials needed should be considered. Nevertheless, the current energy situation and future issues, such as population growth and increased standard of living, will inevitably demand a safe, affordable and sustainable solution to the shortage of fossil fuel and environmental effects such as global warming. Chromogenic technology and thin film materials will play an important role in finding the appropriate solution. 
Acknowledgments: Işıl Top thanks TUBITAK for the provision of funding for a studentship. Shuqun Chen thanks the China Scholarship Council for the provision of a studentship.

Conflicts of Interest: The authors declare no conflict of interest.

\section{References}

1. Anstock, J.S. Handbook of Glass in Construction; McGraw-Hill Publication: New York, NY, USA, 1997.

2. Watts, A. Modern Construction Envelopes; Springer: Vienna, Austria; New York, NY, USA, 2010.

3. Kanu, S.S.; Binions, R. Thin films for solar control. Proc. R. Soc. Math. Phys. Eng. Sci. 2010, 466, 19-44. [CrossRef]

4. European Comission. Directive 2002/91/EC of the European Parliament and of the Council of 16 December 2002 on the Energy Performance of Buildings; European Comission: Brussells, Belgium, 2002.

5. United Nations. Kyoto Protocol to the United Nations Framework Convention on Climate Change; United Nations: Bonn, Germany, 1997.

6. Granqvist, C.G. Smart windows. Adv. Sci. Technol. 2008, 55, 205-212. [CrossRef]

7. Pilkington Glass Handbook, 2010. Available online: http://www.pilkington.com/resources/ glasshandbook2010english.pdf (accessed on 12 September 2016).

8. Parkin, I.P.; Palgrave, R.G. Self-cleaning coatings. J. Mater. Chem. 2005, 15, 1689-1695. [CrossRef]

9. Warwick, M.E.A.; Ridley, I.; Binions, R. The effect of transition gradient in thermochromic glazing systems. Energy Build. 2014, 77, 80-90. [CrossRef]

10. Stadler, A. Transparent Conducting Oxides-An Up-To-Date Overview. Materials 2012, 5, 661-683. [CrossRef]

11. Warwick, M.E.A.; Binions, R. Chemical vapour deposition of thermochromic vanadium dioxide thin films for energy efficient glazing. J. Solid State Chem. 2014, 214, 53-66. [CrossRef]

12. O'Keeffe, C.; Gannon, P.; Gilson, P.; Kafizas, A.; Parkin, I.P.; Binions, R. Air purification by heterogeneous photocatalytic oxidation with multi-doped thin film titanium dioxide. Thin Solid Films 2013, 537, 131-136. [CrossRef]

13. Miyazaki, T.; Akisawa, A.; Kashiwagi, T. Energy savings of office buildings by the use of semi-transparent solar cells for windows. Renew. Energy 2005, 30, 281-304. [CrossRef]

14. Jelle, B.P.; Hynd, A.; Gustavsen, A.; Arasteh, D.; Goudey, H.; Hart, R. Fenestration of today and tomorrow: A state-of-art review and future research opportunities. Sol. Energy Mater. Sol. Cells 2012, 96, 1-28. [CrossRef]

15. SGG Bioclean Natura. Available online: http://uk.saint-gobain-glass.com/product/783/sgg-biocleannatura (accessed on 15 March 2016).

16. SGG Bioclean Aqua. Available online: http://uk.saint-gobain-glass.com/product/782/sgg-bioclean-aqua (accessed on 15 March 2016).

17. PPG Sunclean. Available online: http://corporate.ppg.com/Businesses/Specialty-Coatings-and-Materials. aspx (accessed on 15 March 2016).

18. Viridian Renew. Available online: http://www.viridianglass.com/products/clear-vision/renew (accessed on 15 March 2016).

19. Vernardou, D.; Drosos, H.; Fasoulas, J.; Koudoumas, E.; Katsarakis, N. Photocatalytic properties of chemically grown vanadium oxide at $65^{\circ} \mathrm{C}$. Thin Solid Films 2014, 555, 169-172. [CrossRef]

20. Lim, J.; Monllor-Satoca, D.; Jang, J.S.; Lee, S.; Choi, W. Visible light photocatalysis of fullerol-complexed $\mathrm{TiO}_{2}$ enhanced by $\mathrm{Nb}$ doping. Appl. Catal. B Environ. 2014, 152-153, 233-240. [CrossRef]

21. Srinivasan, S.S.; Wade, J.; Stefanakos, E.K.; Goswami, Y. Synergistic effects of sulfation and co-doping on the visible light photocatalysis of $\mathrm{TiO}_{2}$. J. Alloys Compd. 2006, 424, 322-326. [CrossRef]

22. Anandan, S.; Narasinga Rao, T.; Sathish, M.; Rangappa, D.; Honma, I.; Miyauchi, M. Superhydrophilic graphene-loaded $\mathrm{TiO}_{2}$ thin film for self-cleaning applications. ACS Appl. Mater. Interfaces 2012, 5, $207-212$. [CrossRef] [PubMed]

23. Faustini, M.; Nicole, L.; Boissière, C.; Innocenzi, P.; Sanchez, C.; Grosso, D. Hydrophobic, antireflective, self-cleaning, and antifogging sol-gel coatings: An example of multifunctional nanostructured materials for photovoltaic cells. Chem. Mater. 2010, 22, 4406-4413. [CrossRef]

24. $\mathrm{Mu}, \mathrm{Q}$; $\mathrm{Li}, \mathrm{Y}$.; Zhang, $\mathrm{Q}$. Self organized $\mathrm{TiO}_{2}$ nanorod arrays on glass substrate for self-cleaning antireflection coatings. J. Colloid Interface Sci. 2012, 365, 308-313. [CrossRef] [PubMed] 
25. Midtdal, K.; Jelle, B.P. Self-cleaning glazing products: A state-of-the-art review and future research pathways. Sol. Energy Mater. Sol. Cells 2013, 109, 126-141. [CrossRef]

26. Cannavale, A.; Fiorito, F.; Manca, M.; Tortorici, G.; Cingolani, R.; Gigli, G. Multifunctional bioinspired sol-gel coatings for architectural glasses. Build. Environ. 2010, 45, 1233-1243. [CrossRef]

27. Cassie, A.B.D.; Baxter, S. Wettability of porous surfaces. Trans. Faraday Soc. 1944, 40, 546-551. [CrossRef]

28. Marmur, A. Wetting on hydrophobic rough surfaces: To be heterogeneous or not to be? Langmuir 2003, 19, 8343-8348. [CrossRef]

29. Neinhuis, C.; Barthlott, W. Characterization and Distribution of Water-repellent, Self-cleaning Plant Surfaces. Ann. Bot. 1997, 79, 667-677. [CrossRef]

30. Michael, N.; Bhushan, B. Hierarchical roughness makes superhydrophobic states stable. Microelectron. Eng. 2007, 84, 382-386. [CrossRef]

31. Mills, A.; Hill, G.; Bhopal, S.; Parkin, I.P.; O'Neill, S.A. Thick titanium dioxide films for semiconductor photocatalysis. J. Photochem. Photobiol. A Chem. 2003, 160, 185-194. [CrossRef]

32. Nakata, K.; Fujishima, A. $\mathrm{TiO}_{2}$ photocatalysis: Design and applications. J. Photochem. Photobiol. C Photochem. Rev. 2012, 13, 169-189. [CrossRef]

33. Liang, J.; Zhu, G.-Q.; Liu, P.; Xu, C. Highly Visible-Light-Responsive Photocatalytic AgCl/BiOCl Hetero-Nanostructures Synthesized by a Chemical Coprecipitation Method. J. Nanosci. Nanotechnol. 2014, 14, 4185-4190. [CrossRef] [PubMed]

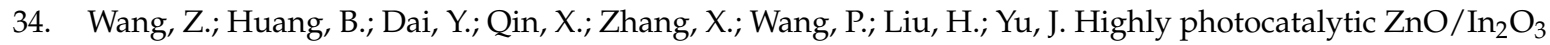
heteronanostructures synthesized by a coprecipitation method. J. Phys. Chem. C 2009, 113, 4612-4617. [CrossRef]

35. He, C.; Gu, M. Photocatalytic activity of bismuth germanate $\mathrm{Bi}_{12} \mathrm{GeO}_{20}$ powders. Scr. Mater. 2006, 54, 1221-1225. [CrossRef]

36. Yin, J.; Zou, Z.; Ye, J. Possible Role of Lattice Dynamics in the Photocatalytic Activity of BaM $\mathrm{B}_{1 / 3} \mathrm{~N}_{2 / 3} \mathrm{O}_{3}$ $(\mathrm{M}=\mathrm{Ni}, \mathrm{Zn} ; \mathrm{N}=\mathrm{Nb}$, Ta). J. Phys. Chem. B 2004, 108, 8888-8893. [CrossRef]

37. Romero, L.; Binions, R. Effect of AC electric fields on the aerosol assisted chemical vapour deposition growth of titanium dioxide thin films. Surf. Coat. Technol. 2013, 230, 196-201. [CrossRef]

38. Romero, L.; Binions, R. On the Influence of DC Electric Fields on the Aerosol Assisted Chemical Vapor Deposition Growth of Photoactive Titanium Dioxide Thin Films. Langmuir 2013, 29, 13542-13550. [CrossRef] [PubMed]

39. Mao, L.; Wang, Y.; Zhong, Y.; Ning, J.; Hu, Y. Microwave-assisted deposition of metal sulfide/oxide nanocrystals onto a 3D hierarchical flower-like $\mathrm{TiO}_{2}$ nanostructure with improved photocatalytic activity. J. Mater. Chem. A 2013, 1, 8101-8104. [CrossRef]

40. Andersson, M.; Birkedal, H.; Franklin, N.R.; Ostomel, T.; Boettcher, S.; Palmqvist, A.E.C.; Stucky, G.D. $\mathrm{Ag} / \mathrm{AgCl}-$ loaded ordered mesoporous anatase for photocatalysis. Chem. Mater. 2005, 17, 1409-1415. [CrossRef]

41. Sonawane, R.S.; Dongare, M.K. Sol-gel synthesis of $\mathrm{Au} / \mathrm{TiO}_{2}$ thin films for photocatalytic degradation of phenol in sunlight. J. Mol. Catal. A Chem. 2006, 243, 68-76. [CrossRef]

42. Zhang, N.; Liu, S.; Fu, X.; Xu, Y.J. Synthesis of $\mathrm{M} @ T i O_{2}(\mathrm{M}=\mathrm{Au}, \mathrm{Pd}, \mathrm{Pt})$ Core-Shell Nanocomposites with Tunable Photoreactivity. J. Phys. Chem. C 2011, 115, 9136-9145. [CrossRef]

43. Tian, G.; Chen, Y.; Zhai, R.; Zhou, J.; Zhou, W.; Wang, R.; Pan, K.; Tian, C.; Fu, H. Hierarchical flake-like $\mathrm{Bi}_{2} \mathrm{MoO}_{6} / \mathrm{TiO}_{2}$ bilayer films for visible-light-induced self-cleaning applications. J. Mater. Chem. A 2013, 1 , 6961-6968. [CrossRef]

44. Yu, H.; Huang, J.; Zhang, H.; Zhao, Q.; Zhong, X. Nanostructure and charge transfer in $\mathrm{Bi}_{2} \mathrm{~S}_{3}-\mathrm{TiO}_{2}$ heterostructures. Nanotechnology 2014, 25, 215702. [CrossRef] [PubMed]

45. Wang, Y.; Yu, K.; Yin, H.; Song, C.; Zhang, Z.; Li, S.; Shi, H.; Zhang, Q.; Zhao, B.; Zhang, Y.; et al. Facile synthesis, enhanced field emission and photocatalytic activities of $\mathrm{Cu}_{2} \mathrm{O}-\mathrm{TiO}_{2}-\mathrm{ZnO}$ ternary hetero-nanostructures. J. Phys. D Appl. Phys. 2013, 46, 175303. [CrossRef]

46. Gohin, M.; Allain, E.; Chemin, N.; Maurin, I.; Gacoin, T.; Boilot, J.P. Sol-gel nanoparticulate mesoporous films with enhanced self-cleaning properties. J. Photochem. Photobiol. A Chem. 2010, 216, 142-148. [CrossRef]

47. Tachikawa, T.; Takai, Y.; Tojo, S.; Fujitsuka, M.; Irie, H.; Hashimoto, K.; Majima, T. Visible Light-Induced Degradation of Ethylene Glycol on Nitrogen-Doped $\mathrm{TiO}_{2}$ Powders. J. Phys. Chem. B 2006, 110, 13158-13165. [CrossRef] [PubMed] 
48. Xu, Q.; Wellia, D.V.; Sk, M.A.; Lim, K.H.; Loo, J.S.C.; Liao, D.W.; Amal, R.; Tan, T.T.Y. Transparent visible light activated $\mathrm{C}-\mathrm{N}-\mathrm{F}$-codoped $\mathrm{TiO}_{2}$ films for self-cleaning applications. J. Photochem. Photobiol. A Chem. 2010, 210, 181-187. [CrossRef]

49. Li, D.; Haneda, H.; Hishita, S.; Ohashi, N. Visible-Light-Driven N-F-Codoped $\mathrm{TiO}_{2}$ Photocatalysts. 2. Optical Characterization, Photocatalysis, and Potential Application to Air Purification. Chem. Mater. 2005, 17, 2596-2602. [CrossRef]

50. Zhao, X.; Zhao, Q.; Yu, J.; Liu, B. Preparation and properties of chalcogenide glasses in the $\mathrm{GeS}_{2}-\mathrm{Sb}_{2} \mathrm{~S}_{3}-\mathrm{CdS}$ system. J. Non-Cryst. Solids 2008, 354, 462-467. [CrossRef]

51. Kesmez, Ö.; Erdem Çamurlu, H.; Burunkaya, E.; Arpaç, E. Sol-gel preparation and characterization of anti-reflective and self-cleaning $\mathrm{SiO}_{2}-\mathrm{TiO}_{2}$ double-layer nanometric films. Sol. Energy Mater. Sol. Cells 2009, 93, 1833-1839. [CrossRef]

52. Prado, R.; Beobide, G.; Marcaide, A.; Goikoetxea, J.; Aranzabe, A. Development of multifunctional sol-gel coatings: Anti-reflection coatings with enhanced self-cleaning capacity. Sol. Energy Mater. Sol. Cells 2010, 94, 1081-1088. [CrossRef]

53. Askar, K.; Phillips, B.M.; Fang, Y.; Choi, B.; Gozubenli, N.; Jiang, P.; Jiang, B. Self-assembled self-cleaning broadband anti-reflection coatings. Colloids Surf. A Physicochem. Eng. Asp. 2013, 439, 84-100. [CrossRef]

54. Verma, L.K.; Sakhuja, M.; Son, J.; Danner, A.J.; Yang, H.; Zeng, H.C.; Bhatia, C.S. Self-cleaning and antireflective packaging glass for solar modules. Renew. Energy 2011, 36, 2489-2493. [CrossRef]

55. Deubener, J.; Helsch, G.; Moiseev, A.; Bornhöft, H. Glasses for solar energy conversion systems. J. Eur. Ceram. Soc. 2009, 29, 1203-1210. [CrossRef]

56. Ding, X.; Zhou, S.; Wu, L.; Gu, G.; Yang, J. Formation of supra-amphiphilic self-cleaning surface through sun-illumination of titania-based nanocomposite coatings. Surf. Coat. Technol. 2010, 205, 2554-2561. [CrossRef]

57. Kapridaki, C.; Maravelaki-Kalaitzaki, P. $\mathrm{TiO}_{2}-\mathrm{SiO}_{2}-\mathrm{PDMS}$ nano-composite hydrophobic coating with self-cleaning properties for marble protection. Prog. Org. Coat. 2013, 76, 400-410. [CrossRef]

58. Kapridaki, C.; Pinho, L.; Mosquera, M.J.; Maravelaki-Kalaitzaki, P. Producing photoactive, transparent and hydrophobic $\mathrm{SiO}_{2}$-crystalline $\mathrm{TiO}_{2}$ nanocomposites at ambient conditions with application as self-cleaning coatings. Appl. Catal. B Environ. 2014, 156-157, 416-427. [CrossRef]

59. PPG SunClean. Available online: http://corporate.ppg.com/Businesses/Specialty-Coatings-and-Materials. aspx (accessed on 15 March 2016).

60. Wulf, M.; Wehling, A.; Reis, O. Coatings with self-cleaning properties. Macromol. Symp. 2002, 187, 459-468. [CrossRef]

61. Verho, T.; Bower, C.; Andrew, P.; Franssila, S.; Ikkala, O.; Ras, R.H. Mechanically durable superhydrophobic surfaces. Adv. Mater. 2011, 23, 673-678. [CrossRef] [PubMed]

62. Warwick, M.E.A.; Binions, R. Advances in thermochromic vanadium dioxide films. J. Mater. Chem. A 2014, 2, 3275-3292. [CrossRef]

63. Parkin, I.P.; Manning, T.D. Intelligent thermochromic windows. J. Chem. Educ. 2006, 83, 393-400. [CrossRef]

64. Warwick, M.E.A.; Hyett, G.; Ridley, I.; Laffir, F.R.; Olivero, C.; Chapon, P.; Binions, R. Synthesis and energy modelling studies of titanium oxy-nitride films as energy efficient glazing. Sol. Energy Mater. Sol. Cells 2013, 118, 149-156. [CrossRef]

65. Dowling, R.; McGuirk, P.; Bulkeley, H. Retrofitting cities: Local governance in Sydney, Australia. Cities 2014, 38, 18-24. [CrossRef]

66. Guan, X.; Xu, Z.; Jia, Q.S. Energy-efficient buildings facilitated by microgrid. IEEE Trans. Smart Grid 2010, 1, 243-252. [CrossRef]

67. Granqvist, C.G. Transparent conductors as solar energy materials: A panoramic review. Sol. Energy Mater. Sol. Cells 2007, 91, 1529-1598. [CrossRef]

68. Jones, A.C.; Hitchman, M.L. Chemical Vapour Deposition: Precursors, Processes and Applications. R. Soc. Chem. Camb. 2009, 48, 7478-7479.

69. Szczyrbowski, J.; Dietrich, A.; Hartig, K. Bendable silver-based low emissivity coating on glass. Sol. Energy Mater. 1989, 19, 43-53. [CrossRef]

70. Pasquarelli, R.M.; Ginley, D.S.; O'Hayre, R. Solution processing of transparent conductors: From flask to film. Chem. Soc. Rev. 2011, 40, 5406-5441. [CrossRef] [PubMed] 
71. Hartnagel, H.L.; Dawar, A.L.; Jain, A.K.; Jagadish, H. Semiconducting Transparent Thin Films; Institute of Physics Publishing: Bristol, UK; Philedelphia, PA, USA, 1995.

72. Banerjee, R.; Ray, S.; Basu, N.; Batabyal, A.K.; Barua, A.K. Degradation studies of Indium Tin Oxide films in hydrogen and argon plasma. J. Appl. Phys. 1987, 62, 912-916. [CrossRef]

73. Buchanan, M.; Webb, J.B.; Williams, D.F. Preparation of conducting and transparent thin films of tin-doped indium oxide by magnetron sputtering. Appl. Phys. Lett. 1980, 37, 213-215. [CrossRef]

74. Maki, K.; Komiya, N.; Suzuki, A. Fabrication of thin films of ITO by aerosol CVD. Thin Solid Films 2003, 445, 224-228. [CrossRef]

75. Rydzek, M.; Reidinger, M.; Arduini-Schuster, M.; Manara, J. Comparative study of sol-gel derived tin-doped indium- and aluminum-doped zinc-oxide coatings for electrical conducting and low-emitting surfaces. Prog. Org. Coat. 2011, 70, 369-375. [CrossRef]

76. Frank, G.; Kauer, E.; Köstlin, H.; Schmitte, F.J. Transparent heat-reflecting coatings for solar applications based on highly doped tin oxide and indium oxide. Sol. Energy Mater. 1983, 8, 387-398. [CrossRef]

77. Kim, H.; Horwitz, J.S.; Kushto, G.; Piqué, A.; Kafafi, Z.H.; Gilmore, C.M.; Chrisey, D.B. Effect of film thickness on the properties of indium tin oxide thin films. J. Appl. Phys. 2000, 88, 6021-6025. [CrossRef]

78. China Yaohua Glass Group Corporation. Coated Glass Production Line. Available online: http://www. yaohuachina.com/linemore.asp?id=20 (accessed on 1 April 2016).

79. Yamada, T.; Makino, H.; Yamamoto, N.; Yamamoto, T. Ingrain and grain boundary scattering effects on electron mobility of transparent conducting polycrystalline Ga-doped ZnO films. J. Appl. Phys. 2010, 107, 123534. [CrossRef]

80. Noor, N.; Parkin, I.P. Enhanced transparent-conducting fluorine-doped tin oxide films formed by Aerosol-Assisted Chemical Vapour Deposition. J. Mater. Chem. C 2013, 1, 984-996. [CrossRef]

81. AGC Solar. Coated Glass. Available online: http://www.agc-solar.com/agc-solar-products/coated-glass html (accessed on 1 April 2016).

82. Shanthi, E. Electrical and Optical Properties of Tin Oxide Films Doped with F and (Sb + F). J. Appl. Phys. 1982, 53, 1615-1621. [CrossRef]

83. Batzill, M.; Diebold, U. The Surface and Materials Science of Tin Oxide. Prog. Surf. Sci. 2005, 79, 47-154. [CrossRef]

84. Bhachu, D.S.; Waugh, M.R.; Zeissler, K.; Branford, W.R.; Parkin, I.P. Textured Fluorine-Doped Tin Dioxide Films Formed by Chemical Vapour Deposition. Chemistry 2011, 17, 11613-11621. [CrossRef] [PubMed]

85. Dong, B.Z.; Fang, G.J.; Wang, J.F.; Guan, W.J.; Zhao, X.Z. Effect of Thickness on Structural, Electrical, and Optical Properties of ZnO: Al Films Deposited by Pulsed Laser Deposition. J. Appl. Phys. 2007, 101, 033713. [CrossRef]

86. Zhu, M.W.; Gong, J.; Sun, C.; Xia, J.H.; Jiang, X. Investigation of Correlation between the Microstructure and Electrical Properties of Sol-Gel Derived ZnO Based Thin Films. J. Appl. Phys. 2008, 104, 073113. [CrossRef]

87. Hu, J.; Gordon, R.G. Textured Aluminum-Doped Zinc Oxide Thin Films from Atmospheric Pressure Chemical-Vapor Deposition. J. Appl. Phys. 1992, 71, 880-890. [CrossRef]

88. Hu, J.; Gordon, R.G. Atmospheric Pressure Chemical Vapor Deposition of Gallium Doped Zinc Oxide Thin Films from Diethyl Zinc, Water, and Triethyl Gallium. J. Appl. Phys. 1992, 72, 5381-5392. [CrossRef]

89. Bhachu, D.S.; Sankar, G.; Parkin, I.P. Aerosol Assisted Chemical Vapor Deposition of Transparent Conductive Zinc Oxide Films. Chem. Mater. 2012, 24, 4704-4710. [CrossRef]

90. Kim, I.; Lee, K.S.; Lee, T.S.; Jeong, J.; Cheong, B.; Baik, Y.J.; Kim, W.M. Effect of Fluorine Addition on Transparent and Conducting Al Doped ZnO Films. J. Appl. Phys. 2006, 100, 063701. [CrossRef]

91. Ma, Q.B.; Ye, Z.Z.; He, H.P.; Zhu, L.P.; Huang, J.Y.; Zhang, Y.Z.; Zhao, B.H. Influence of Annealing Temperature on the Properties of Transparent Conductive and near-Infrared Reflective ZnO:Ga Films. Scr. Mater. 2008, 58, 21-24. [CrossRef]

92. Elleuch, R.; Salhi, R.; Maalej, N.; Deschanvres, J.L.; Maalej, R. Structural and Luminescence Correlation of Annealed Er-ZnO/Si Thin Films Deposited by AACVD Process. Mater. Sci. Eng. B 2013, 178, 1124-1129. [CrossRef]

93. Waugh, M.R.; Hyett, G.; Parkin, I.P. Zinc Oxide Thin Films Grown by Aerosol Assisted CVD. Chem. Vap. Depos. 2008, 14, 366-372. [CrossRef]

94. Choy, K.L. Chemical Vapor Deposition. Prog. Mater. Sci. 2001, 48, 57. [CrossRef] 
95. World Meteorological Organization (WMO). The Changing Atmosphere: Implications for Global Security; Secretariat of the World Meteorological Organization: Geneva, Switzerland, 1989.

96. Peng, C.; Huang, Y.; Wu, Z. Building-Integrated Photovoltaics (BIPV) in Architectural Design in China. Energy Build. 2011, 43, 3592-3598. [CrossRef]

97. Petter Jelle, B.; Breivik, C.; Drolsum Røkenes, H. A State-of-the-Art Review and Future Research Opportunities. Sol. Energy Mater. Sol. Cells 2012, 100, 69-96. [CrossRef]

98. Eperon, G.E.; Burlakov, V.M.; Goriely, A.; Snaith, H.J. Neutral Color Semitransparent Microstructured Perovskite Solar Cells. ACS Nano 2014, 8, 591-598. [CrossRef] [PubMed]

99. Krebs, F.C.; Tromholt, T.; Jørgensen, M. Upscaling of Polymer Solar Cell Fabrication Using Full Roll-to-Roll Processing. Nanoscale 2010, 2, 873-886. [CrossRef] [PubMed]

100. O’Regan, B.; Grätzel, M. A Low-Cost, High-Efficiency Solar Cell Based on Dye-Sensitized Colloidal TiO 2 Films. Nature 1991, 353, 737-740. [CrossRef]

101. Nakade, S.; Kanzaki, T.; Kambe, S.; Wada, Y.; Yanagida, S. Investigation of Cation-Induced Degradation of Dye-Sensitized Solar Cells for a New Strategy to Long-Term Stability. Langmuir 2005, 21, 11414-11417. [CrossRef] [PubMed]

102. Park, N.G.; Van de Lagemaat, J.; Frank, A.J. Comparison of Dye-Sensitized Rutile-and Anatase-Based $\mathrm{TiO}_{2}$ Solar Cells. J. Phys. Chem. 2000, 104, 8989-8994. [CrossRef]

103. Bozic-Weber, B.; Constable, E.C.; Housecroft, C.E. Light Harvesting with Earth Abundant D-Block Metals: Development of Sensitizers in Dye-Sensitized Solar Cells (DSCs). Coord. Chem. Rev. 2013, 257, 3089-3106. [CrossRef]

104. Gutiérrez-Tauste, D.; Zumeta, I.; Vigil, E.; Hernández-Fenollosa, M.A.; Domènech, X.; Ayllón, J.A. New Low-Temperature Preparation Method of the $\mathrm{TiO}_{2}$ Porous Photoelectrode for Dye-Sensitized Solar Cells Using UV Irradiation. J. Photochem. Photobiol. A Chem. 2005, 175, 165-171. [CrossRef]

105. Yella, A.; Lee, H.W.; Tsao, H.N.; Yi, C.; Chandiran, A.K.; Nazeeruddin, M.K.; Diau, E.W.G.; Yeh, C.-Y.; Zakeeruddin, S.M.; Grätzel, M. Porphyrin-Sensitized Solar Cells with Cobalt (II/III)-Based Redox Electrolyte Exceed 12 Percent Efficiency. Science 2011, 334, 629-634. [CrossRef] [PubMed]

106. Kalyanasundaram, K.; Gratzel, M. Applications of Functionalized Transition Metal Complexes in Photonic and Optoelectronic Devices. Coord. Chem. Rev. 1998, 177, 347-414. [CrossRef]

107. Tian, H.; Jiang, X.; Yu, Z. Efficient Organic-Dye-Sensitized Solar Cells Based on an Iodine-Free Electrolyte. Angew. Chem. Int. Ed. Engl. 2010, 49, 7328-7231. [CrossRef] [PubMed]

108. Grätzel, M. Dye-Sensitized Solar Cells. J. Photochem. Photobiol. C Photochem. Rev. 2003, 4, 145-153. [CrossRef]

109. Green, M.A.; Emery, K.; Hishikawa, Y.; Warta, W.; Dunlop, E.D. Solar Cell Efficiency Tables (Version 38). Prog. Photovolt. Res. Appl. 2011, 19, 565-572. [CrossRef]

110. Ito, S.; Zakeeruddin, S.M.; Humphry-Baker, R.; Liska, P.; Charvet, R.; Comte, P.; Nazeeruddin, M.K.; Péchy, P.; Takata, M.; Miura, H.; et al. High-Efficiency Organic-Dye-Sensitized Solar Cells Controlled by Nanocrystalline- $\mathrm{TiO}_{2}$ Electrode Thickness. Adv. Mater. Adv. Mater. 2006, 18, 1202-1205. [CrossRef]

111. Bella, F.; Bongiovanni, R. Photoinduced Polymerization: An Innovative, Powerful and Environmentally Friendly Technique for the Preparation of Polymer Electrolytes for Dye-Sensitized Solar Cells. J. Photochem. Photobiol. C Photochem. Rev. 2013, 16, 1-12. [CrossRef]

112. Tributsch, H. Dye Sensitization Solar Cells: A Critical Assessment of the Learning Curve. Coord. Chem. Rev. 2004, 248, 1511-1530. [CrossRef]

113. Cao, Y.; Zhang, J.; Bai, Y.; Li, R.; Zakeeruddin, S.M.; Grätzel, M.; Wang, P. Dye-Sensitized Solar Cells with Solvent-Free Ionic Liquid Electrolytes. J. Phys. Chem. C 2008, 112, 13775-13781. [CrossRef]

114. Ileperuma, O.A. Gel Polymer Electrolytes for Dye Sensitised Solar Cells: A Review. Mater. Technol. Adv. Perform. Mater. 2013, 28, 65-70. [CrossRef]

115. Nei de Freitas, J.; Nogueira, A.F.; De Paoli, M.A. New Insights into Dye-Sensitized Solar Cells with Polymer Electrolytes. J. Mater. Chem. 2009, 19, 5279-5294. [CrossRef]

116. Tennakone, K.; Perera, V.P.S.; Kottegoda, I.R.M.; Kumara, G.R.R.A. Dye-Sensitized Solid State Photovoltaic Cell Based on Composite Zinc Oxide/tin (IV) Oxide Films. J. Phys. D Appl. Phys. 1999, 32, 374-379. [CrossRef]

117. Cai, N.; Moon, S.J.; Cevey-Ha, L.; Moehl, T.; Humphry-Baker, R.; Wang, P.; Zakeeruddin, S.M.; Grätzel, M. An organic $D-\pi$-A dye for record efficiency solid-state sensitized heterojunction solar cells. Nano Lett. 2011, 11, 1452-1456. [CrossRef] [PubMed] 
118. Liu, X.; Zhang, W.; Uchida, S.; Cai, L.; Liu, B.; Ramakrishna, S. An efficient organic-dye-sensitized solar cell with in situ polymerized poly(3,4-ethylenedioxythiophene) as a hole-transporting material. Adv. Mater. 2010, 22, E150-E155. [CrossRef] [PubMed]

119. Upadhyaya, H.M.; Senthilarasu, S.; Hsu, M.H.; Kumar, D.K. Recent Progress and the Status of Dye-Sensitised Solar Cell (DSSC) Technology with State-of-the-Art Conversion Efficiencies. Sol. Energy Mater. Sol. Cells 2013, 119, 291-295. [CrossRef]

120. Hardin, B.E.; Snaith, H.J.; McGehee, M.D. The renaissance of dye-synthesized solar cells. Nat. Photon. 2012, 6, 162-169. [CrossRef]

121. Norton, B.; Eames, P.C.; Mallick, T.K.; Huang, M.J.; McCormack, S.J.; Mondol, J.D.; Yohanis, Y.G. Enhancing the performance of building integrated photoviltaics. Sol. Energy 2011, 85, 1629-1664. [CrossRef]

122. Kim, Y.H.; Müller-Meskamp, L.; Zakhidov, A.A.; Sachse, C.; Meiss, J.; Bikova, J.; Cook, A.; Zakhidov, A.A.; Leo, K. Semi transparent small molecule organic solar cells with laminated free-standing carbon nanotube top electrodes. Sol. Energy Mater. Sol. Cells 2012, 96, 244-250. [CrossRef]

123. Czolk, J.; Puetz, A.; Kutsarov, D. Manuel Reinhard, Uli Lemmer, Alexander Colsmann. Inverted Semi-transparent Polymer Solar Cells with Transparency Color Rendering Indices approaching 100. Adv. Energy Mater. 2013, 3, 386-390. [CrossRef]

124. Tang, Z.; George, Z.; Ma, Z. Semi-transparent tandem organic solar cells with $90 \%$ Internal Quantum Efficiency. Adv. Energy Mater. 2012, 2, 1467-1476. [CrossRef]

125. Zhou, Y.; Cheun, H.; Choi, S.; Fuentes-Hernandez, C.; Kippelen, B. Optimization of a polymer top electrode for inverted semitransparent organic solar cells. Org. Electron. 2011, 12, 827-831. [CrossRef]

126. Chueh, C.C.; Chien, S.C.; Yip, H.L.; Salinas, J.F.; Li, C.Z.; Chen, K.S.; Chen, F.C.; Chen, W.C.; Jen, A.K.Y. Toward high-performance semi-transparent polymer solar cells: Optimization of ultra-thin light absorbing layer and transparent cathode architecture. Adv. Energy Mater. 2013, 3, 417-423. [CrossRef]

127. Hanisch, J.; Ahlswede, E.; Powalla, M. All sputtered contacts for organic solar cells. Thin Solid Films 2008, 516, 7241-7244. [CrossRef]

128. Park, H.; Chang, S.; Smith, M.; Gradecak, S.; Kong, J. Interface engineering of graphene for universal applications as both anode and cathode in organic photovoltaics. Sci. Rep. 2013, 3, 1581. [CrossRef] [PubMed]

129. Krantz, J.; Stubhan, T.; Richter, M.; Spallek, S.; Litzov, I.; Matt, G.J.; Spiecker, E.; Brabec, C.J. Spray-coated silver nanowires as top electrode layer in semitransparent P3HT:PCBM-based organic solar cell devices. Adv. Funct. Mater. 2013, 23, 1711-1717. [CrossRef]

130. Garnett, E.C.; Cai, W.; Cha, J.J. Self-limited plasmonic welding of silver nanowire junctions. Nat. Mater. 2012, 11, 241-249. [CrossRef] [PubMed]

131. Lee, J.Y.; Connor, S.T.; Cui, Y.; Peumans, P. Semi-transparent organic photovoltaic cells with laminated top electrode. Nano Lett. 2010, 10, 1276-1279. [CrossRef] [PubMed]

132. Guo, F.; Zhu, X.; Forberich, K.; Krantz, J.; Stubhan, T.; Salinas, M.; Halik, M.; Spallek, S.; Butz, B.; Spiecker, E.; et al. ITO-Free and Fully Solution-Processed Semitransparent Organic Solar Cells with High Fill Factors. Adv. Energy Mater. 2013, 3, 1062-1067. [CrossRef]

133. Reinhard, M.; Eckstein, R.; Slobodskyy, A.; Lemmer, U.; Colsmann, A. Solution-processed polymer-silver nanowire top electrodes for inverted semi-transparent solar cells. Org. Electron. 2013, 14, 273-277. [CrossRef]

134. Beiley, Z.M.; Christoforo, M.G.; Gratia, P.; Bowring, A.R.; Eberspacher, P.; Margulis, G.Y.; Cabanetos, C.; Beaujuge, P.M.; Salleo, A.; McGehee, M.D. Semi-Transparent Polymer Solar Cells with Excellent Sub-Bandgap Transmission for Third Generation Photovoltaics. Adv. Mater. 2013, 25, 7020-70226. [CrossRef] [PubMed]

135. New Energy Technologies Inc. Solar WindowTM Clearly Electric. Available online: http://www.solarwindow. com (accessed on 22 April 2016).

136. National Center for Photovoltaics (NREL). Best Research Cell Efficiencies. Available online: http:/ / www. nrel.gov/ncpv/images/efficiency_chart.jpg (accessed on 23 April 2016).

137. Jørgensen, M.; Norrman, K.; Gevorgyan, S.A.; Tromholt, T.; Andreasen, B.; Krebs, F.C. Stability of polymer solar cells. Adv. Mater. 2012, 24, 580-612. [CrossRef] [PubMed]

138. Chen, K.S.; Salinas, J.F.; Yip, H.L.; Huo, L.; Hou, J.; Jen, A.K.Y. Semi-transparent polymer solar cells with $6 \%$ PCE, 25\% average visible transmittance and a color rendering index close to 100 for power generating window applications. Energy Environ. Sci. 2012, 5, 9551-9557. [CrossRef] 
139. Snaith, H.J. Perovskites: The Emergence of a New Era for Low-Cost, High-Efficiency Solar Cells. J. Phys. Chem. Lett. 2013, 4, 3623-3630. [CrossRef]

140. Burschka, J.; Pellet, N.; Moon, S.J.; Humphry-Baker, R.; Gao, P.; Nazeeruddin, M.K.; Graetzel, M. Sequential deposition as a route to high-performance perovskite-sensitized solar cells. Nature 2013, 499, 316-319. [CrossRef] [PubMed]

141. Liu, M.; Johnston, M.B.; Snaith, H.J. Efficient planar heterojunction perovskite solar cells by vapour deposition. Nature 2013, 501, 395-398. [CrossRef] [PubMed]

142. Scanlon, B. NREL Unlocking Secrets of New Solar Material. Available online: http://www.nrel.gov/news/ features/feature_detail.cfm/feature_id=10333 (accessed on 15 April 2014).

143. Kim, H.S.; Lee, C.R.; Im, J.-H.; Lee, K.B.; Moehl, T.; Marchioro, A.; Moon, S.J.; Humphry-Baker, R.; Yum, J.H.; Moser, J.E.; et al. Lead iodide perovskite sensitized all-solid-state submicron thin film mesoscopic solar cell with efficiency exceeding 9\%. Sci. Rep. 2012, 2, 591. [CrossRef] [PubMed]

144. Poirazis, H.; Blomsterberg, A.; Wall, M. Energy simulations for glazed office buildings in Sweden. Energy Build. 2008, 40, 1161-1170. [CrossRef]

145. Li, D.H.W.; Lam, T.N.T.; Cheung, K.L. Energy and cost studies of semi-transparent photovoltaic skylight. Energy Convers. Manag. 2009, 50, 1981-1990. [CrossRef]

146. Pérez-Lombard, L.; Ortiz, J.; Pout, C. A review on buildings energy consumption information. Energy Build. 2008, 40, 394-398. [CrossRef]

147. Feist, W. Schnieders, Energy efficiency-A key to sustainable housing. Eur. Phys. J. Spec. Top. 2009, 176, 141-153. [CrossRef]

148. Saeli, M.; Piccirillo, C.; Parkin, I.P.; Binions, R.; Ridley, I. Energy modelling studies of thermochromic glazing. Energy Build. 2010, 42, 1666-1673. [CrossRef]

149. Hoffmann, S.; Lee, E.S.; Clavero, C. Examination of the technical potential of near-infrared switching thermochromic windows for commercial building applications. Sol. Energy Mater. Sol. Cells 2014, 123, 65-80. [CrossRef]

150. Narayan, J.; Bhosle, V.M. Phase transition and critical issues in structure-property correlations of vanadium oxide. J. Appl. Phys. 2006, 100, 103524-103526. [CrossRef]

151. Morin, F.J. Oxides Which Show a Metal-to-Insulator Transition at the Neel Temperature. Phys. Rev. Lett. 1959, 3, 34-36. [CrossRef]

152. Batista, C.; Ribeiro, R.M.; Teixeira, V. Synthesis and characterization of $\mathrm{VO}_{2}$-based thermochromic thin films for energy-efficient windows. Nanoscale Res. Lett. 2011, 6, 301. [CrossRef] [PubMed]

153. Alie, D.; Gedvilas, L.; Wang, Z.; Tenent, R.; Engtrakul, C.; Yan, Y.; Shaheen, S.E.; Dillon, A.C.; Ban, C. Direct synthesis of thermochromic $\mathrm{VO}_{2}$ through hydrothermal reaction. J. Solid State Chem. 2014, 212, 237-241. [CrossRef]

154. Long, L.; Ye, H. Discussion of the performance improvement of thermochromic smart glazing applied in passive buildings. Sol. Energy 2014, 107, 236-244. [CrossRef]

155. Ye, H.; Long, L.; Zhang, H.; Xu, B.; Gao, Y.; Kang, L.; Chen, Z. The demonstration and simulation of the application performance of the vanadium dioxide single glazing. Sol. Energy Mater. Sol. Cells 2013, 117, 168-173. [CrossRef]

156. Li, S.Y.; Niklasson, G.A.; Granqvist, C.G. Nanothermochromics: Calculations for $\mathrm{VO}_{2}$ nanoparticles in dielectric hosts show much improved luminous transmittance and solar energy transmittance modulation. J. Appl. Phys. 2010, 108, 063525. [CrossRef]

157. Saeli, M.; Warwick, M.; Piccirllo, C.; Binions, R. Thermochromic Thin Films: Synthesis, Properties and Energy Consumption Modelling. Formatex Res. Cent. 2013, 736-746.

158. Warwick, M.E.A.; Binions, R. On the effects of electric fields in aerosol assisted chemical vapour deposition reactions of vanadyl acetylacetonate solutions in ethanol. J. Nanosci. Nanotechnol. 2011, 11, 1-6. [CrossRef]

159. Zhang, H.; Wu, Z.; Yan, D.; Xu, X.; Jiang, Y. Tunable hysteresis in metal-insulator transition of nanostructured vanadium oxide thin films deposited by reactive direct current magnetron sputtering. Thin Solid Films 2014, 552, 218-224. [CrossRef]

160. Livage, J.; Beteille, F.; Roux, C.; Chatry, M.; Davidson, P. Sol-gel synthesis of oxide materials. Acta Mater. 1998, 46, 743-750. [CrossRef]

161. Burkhardt, W.; Christmann, T.; Meyer, B.K.; Niessner, W.; Schalch, D.; Scharmann, A. W- and F-doped VO 2 films studied by photoelectron spectrometry. Thin Solid Films 1999, 345, 229-235. [CrossRef] 
162. Jin, P.; Tanemura, S. Relationship between Transition Temperature and $\mathrm{x}$ in $V_{1-x} W_{x} \mathrm{O}_{2}$ Films Deposited by Dual-Target Magnetron Sputtering. Jpn. Soc. Appl. Phys. 1995, 34, 2459-2460. [CrossRef]

163. Hanlon, T.J.; Coath, J.A.; Richardson, M.A. Molybdenum-doped vanadium dioxide coatings on glass produced by the aqueous sol-gel method. Thin Solid Films 2003, 436, 269-272. [CrossRef]

164. Mai, L.Q.; Hu, B.; Hu, T.; Chen, W.; Gu, E.D. Electrical Property of Mo-Doped $\mathrm{VO}_{2}$ Nanowire Array Film by Melting-Quenching Sol-Gel Method. J. Phys. Chem. B 2006, 110, 19083-19086. [CrossRef] [PubMed]

165. Manning, T.; Parkin, I.; Blackman, C.; Qureshi, U. APCVD of thermochromic vanadium dioxide thin films-Solid solutions $\mathrm{V}_{2-x} \mathrm{M}_{x} \mathrm{O}_{2}(\mathrm{M}=\mathrm{Mo}, \mathrm{Nb})$ or composites $\mathrm{VO}_{2}$ : $\mathrm{SnO}_{2}$. J. Mater. Chem. 2005, 15, 4560-4566. [CrossRef]

166. Piccirillo, C.; Binions, R.; Parkin, I.P. Nb-Doped $\mathrm{VO}_{2}$ Thin Films Prepared by Aerosol-Assisted Chemical Vapour Deposition. Eur. J. Inorg. Chem. 2007, 2007, 4050-4055. [CrossRef]

167. Mlyuka, N.R.; Niklasson, G.A.; Granqvist, C.G. Mg doping of thermochromic $\mathrm{VO}_{2}$ films enhances the optical transmittance and decreases the metal-insulator transition temperature. Appl. Phys. Lett. 2009, 95, 171909. [CrossRef]

168. Song, L.; Zhang, Y.; Huang, W.; Shi, Q.; Li, D.; Zhang, Y.; Xu, Y. Preparation and thermochromic properties of Ce-doped $\mathrm{VO}_{2}$ films. Mater. Res. Bull. 2013, 48, 2268-2271. [CrossRef]

169. Dai, L.; Chen, S.; Liu, J.; Gao, Y.; Zhou, J.; Chen, Z.; Cao, C.; Luo, H.; Kanehira, M. F-doped VO 2 nanoparticles for thermochromic energy-saving foils with modified color and enhanced solar-heat shielding ability. Phys. Chem. Chem. Phys. 2013, 15, 11723-11729. [CrossRef] [PubMed]

170. Zhang, Z.; Gao, Y.; Chen, Z.; Du, J.; Cao, C.; Kang, L.; Luo, H. Thermochromic VO 2 Thin Films: Solution-Based Processing, Improved Optical Properties, and Lowered Phase Transformation Temperature. Langmuir 2010, 26, 10738-10744. [CrossRef] [PubMed]

171. Warwick, M.E.A.; Binions, R. Thermochromic vanadium dioxide thin films from electric field assisted aerosol assisted chemical vapour deposition. Sol. Energy Mater. Sol. Cells 2015, 143, 592-600. [CrossRef]

172. Wang, B.; Chen, S.; Huang, Z.; Fu, M. Optical nonlinearities of nanostructured $\mathrm{VO}_{2}$ thin films with low phase transition temperature. Appl. Surf. Sci. 2012, 258, 5319-5322. [CrossRef]

173. Guinneton, F.; Sauques, L.; Valmalette, J.C.; Cros, F.; Gavarri, J.R. Optimized infrared switching properties in thermochromic vanadium dioxide thin films: Role of deposition process and microstructure. Thin Solid Films 2004, 446, 287-295. [CrossRef]

174. Kang, L.; Gao, Y.; Zhang, Z.; Du, J.; Cao, C.; Chen, Z.; Luo, H. Effects of Annealing Parameters on Optical Properties of Thermochromic $\mathrm{VO}_{2}$ Films Prepared in Aqueous Solution. J. Phys. Chem. C 2010, 114, 1901-1911. [CrossRef]

175. Zhao, L.; Miao, L.; Tanemura, S.; Zhou, J.; Chen, L.; Xiao, X.; Xu, G. A low cost preparation of $\mathrm{VO}_{2}$ thin films with improved thermochromic properties from a solution-based process. Thin Solid Films 2013, 543, 157-161. [CrossRef]

176. Kang, L.; Xie, L.; Chen, Z.; Gao, Y.; Liu, X.; Yang, Y.; Liang, W. Asymmetrically modulating the insulator-metal transition of thermochromic $\mathrm{VO}_{2}$ films upon heating and cooling by mild surface-etching. Appl. Surf. Sci. 2014, 311, 676-683. [CrossRef]

177. Zhang, H.; Wu, Z.; Wu, X.; Yang, W.; Jiang, Y. Transversal grain size effect on the phase-transition hysteresis width of vanadium dioxide films comprising spheroidal nanoparticles. Vacuum 2014, 104, 47-50. [CrossRef]

178. Xu, Y.; Huang, W.; Shi, Q.; Zhang, Y.; Wu, J.; Song, L. Shape-dependent thermochromic phenomenon in porous nano-structured $\mathrm{VO}_{2}$ films. Mater. Res. Bull. 2013, 48, 4146-4149. [CrossRef]

179. Dai, L.; Cao, C.; Gao, Y.; Luo, H. Synthesis and phase transition behavior of undoped $\mathrm{VO}_{2}$ with a strong nano-size effect. Sol. Energy Mater. Sol. Cells 2011, 95, 712-175. [CrossRef]

180. Minch, R.; Moonoosawmy, K.R.; Solterbeck, C.-H.; Es-Souni, M. The influence of processing conditions on the morphology and thermochromic properties of vanadium oxide films. Thin Solid Films 2014, 556, $277-284$. [CrossRef]

181. Xiao, X.; Zhang, H.; Chai, G.; Sun, Y.; Yang, T.; Cheng, H.; Chen, L.; Miao, L.; Xu, G. A cost-effective process to prepare $\mathrm{VO}_{2}(\mathrm{M})$ powder and films with superior thermochromic properties. Mater. Res. Bull. 2014, 51, 6-12. [CrossRef]

182. Kang, L.; Gao, Y.; Luo, H.; Chen, Z.; Du, J.; Zhang, Z. Nanoporous thermochromic $\mathrm{VO}_{2}$ films with low optical constants, enhanced luminous transmittance and thermochromic properties. ACS Appl. Mater. Interfaces 2011, 3, 135-138. [CrossRef] [PubMed] 
183. Lopez, R.; Haynes, T.; Boatner, L.; Feldman, L.; Haglund, R. Size effects in the structural phase transition of $\mathrm{VO}_{2}$ nanoparticles. Phys. Rev. B 2002, 65, 224113. [CrossRef]

184. Zhang, H.; Wu, Z.; He, Q.; Jiang, Y. Preparation and investigation of sputtered vanadium dioxide films with large phase-transition hysteresis loops. Appl. Surf. Sci. 2013, 277, 218-222. [CrossRef]

185. Ba, C.O.F.; Bah, S.T.; D'Auteuil, M.; Fortin, V.; Ashrit, P.V.; Vallée, R. $\mathrm{VO}_{2}$ thin films based on active and passive thermochromic thermochromic devices for energy management applications. Curr. Appl. Phys. 2014, 14, 1531-1537. [CrossRef]

186. Balu, R.; Ashrit, P.V. Near-zero IR transmission in the metal-insulator transition of $\mathrm{VO}_{2}$ thin films. Appl. Phys. Lett. 2008, 92, 021904. [CrossRef]

187. Niklasson, G.A.; Li, S.Y.; Granqvist, C.G. Thermochromic vanadium oxide thin films: Electronic and optical properties. J. Phys. Conf. Ser. 2014, 559, 012001. [CrossRef]

188. Du, J.; Gao, Y.; Luo, H.; Zhang, Z.; Kang, L.; Chen, Z. Formation and metal-to-insulator transition properties of $\mathrm{VO}_{2}-\mathrm{ZrV}_{2} \mathrm{O}_{7}$ composite films by polymer-assisted deposition. Sol. Energy Mater. Sol. Cells 2011, 95, 1604-1609. [CrossRef]

189. Koo, H.; Shin, D.; Bae, S.-H.; Ko, K.-E.; Chang, S.-H.; Park, C. The Effect of $\mathrm{CeO}_{2}$ Antireflection Layer on the Optical Properties of Thermochromic $\mathrm{VO}_{2}$ Film for Smart Window System. J. Mater. Eng. Perform. 2013, 23, 402. [CrossRef]

190. Kiri, P.; Ridley, I.; Binions, R.; Warwick, M.E.A. Fluorine doped vanadium dioxide thin films for smart windows. Thin Solid Films 2011, 520, 1363-1366. [CrossRef]

191. Li, S.Y.; Mlyuka, N.R.; Primetzhofer, D.; Hallén, A.; Possnert, G.; Niklasson, G.A.; Granqvist, C.G. Bandgap widening in thermochromic $\mathrm{Mg}$-doped $\mathrm{VO}_{2}$ thin films: Quantitative data based on optical absorption. Appl. Phys. Lett. 2013, 103, 161907. [CrossRef]

192. Binions, R.; Piccirillo, C.; Palgrave, R.G.; Parkin, I.P. Hybrid Aerosol Assisted and Atmospheric Pressure CVD of Gold-Doped Vanadium Dioxide. Chem. Vap. Depos. 2008, 14, 33-39. [CrossRef]

193. Wang, N.; Liu, S.; Zeng, X.T.; Magdassi, S.; Long, Y. Mg/W-codoped vanadium dioxide thin films with enhanced visible transmittance and low phase transition temperature. J. Mater. Chem. C 2015, 3, 6771-6777. [CrossRef]

194. Zhou, J.; Gao, Y.; Zhang, Z.; Luo, H.; Cao, C.; Chen, Z.; Dai, L.; Liu, X. VO 2 Thermochromic Smart Window for Energy Savings and Generation. Sci. Rep. 2013, 3, 3029. [CrossRef] [PubMed]

195. Lee, M.H. Thermochromic glazing of windows with better luminous solar transmittance. Sol. Energy Mater. Sol. Cells 2002, 71, 537-540. [CrossRef]

196. Lee, M.H.; Cho, J.S. Better thermochromic glazing of windows with anti-reflection coating. Thin Solid Films 2000, 365, 5-6. [CrossRef]

197. Xu, G.; Jin, P.; Tazawa, M.; Yoshimura, K. Optimization of antireflection coating for $\mathrm{VO}_{2}$-based energy efficient window. Sol. Energy Mater. Sol. Cells 2004, 83, 29-37. [CrossRef]

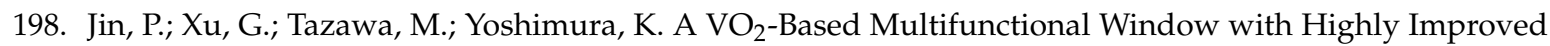
Luminous Transmittance. Jpn. J. Appl. Phys. 2002, 41, L278-L280. [CrossRef]

199. Chen, X.; Lv, Q.; Yi, X. Smart window coating based on nanostructured $\mathrm{VO}_{2}$ thin film. Opt. Int. J. Light Electron Opt. 2012, 123, 1187. [CrossRef]

200. Ji, Y.X.; Li, S.Y.; Niklasson, G.A.; Granqvist, C.G. Durability of thermochromic $\mathrm{VO}_{2}$ thin films under heating and humidity: Effect of Al oxide top coatings. Thin Solid Films 2014, 562, 568-573. [CrossRef]

201. Gagaoudakis, E.; Kortidis, I.; Michail, G.; Tsagaraki, K.; Binas, V.; Kiriakidis, G.; Aperathitis, E. Study of low temperature rf-sputtered $\mathrm{Mg}$-doped vanadium dioxide thermochromic films deposited on low-emissivity substrates. Thin Solid Films 2016, 601, 99-105. [CrossRef]

202. Miller, M.J.; Wang, J. Multilayer ITO/ $\mathrm{VO}_{2} / \mathrm{TiO}_{2}$ thin films for control of solar and thermal spectra. Sol. Energy Mater. Sol. Cells 2016, 154, 88-93. [CrossRef]

203. Yang, Y.; Lee, K.; Zobel, M.; Mackovic, M.; Unruh, T.; Spiecker, E.; Schmuki, P. Formation of Highly Ordered $\mathrm{VO}_{2}$ Nanotubular/Nanoporous Layers and Their Supercooling Effect in Phase Transitions. Adv. Mater. 2012, 24, 1571-1575. [CrossRef] [PubMed]

204. Zhou, M.; Bao, J.; Tao, M.; Zhu, R.; Lin, Y.; Zhanga, X.; Xie, Y. Periodic porous thermochromic $\mathrm{VO}_{2}(\mathrm{M})$ films with enhanced visible transmittance. Chem. Commun. 2013, 49, 6021-6023. [CrossRef] [PubMed]

205. Qian, X.; Wang, N.; Li, Y.; Zhang, J.; Xu, Z.; Long, Y. Bioinspired multifunctional vanadium dioxide: Improved thermochromism and hydrophobicity. Langmuir 2014, 30, 10766-10771. [CrossRef] [PubMed] 
206. Wang, S.; Liu, M.; Kong, L.; Long, Y.; Jiang, X.; Yu, A. Recent progress in $\mathrm{VO}_{2}$ smart coatings: Strategies to improve the thermochromic properties. Prog. Mater. Sci. 2016, 81, 1-54. [CrossRef]

207. Granqvist, C.G. Electrochromics and thermochromics: Toward a new paradigm for energy efficient buildings. Mater. Today Proc. 2016, 3, S2-S11. [CrossRef]

208. Louloudakis, D.; Vernardou, D.; Spanakis, E.; Suchea, M.; Kenanakis, G.; Pemble, M.; Savvakis, C.; Katsarakis, N.; Koudoumas, E.; Kiriakidis, G. Atmospheric pressure chemical vapor deposition of amorphous tungsten doped vanadium dioxide for smart window applications. Adv. Mater. Lett. 2016, 7, 100-150. [CrossRef] article distributed under the terms and conditions of the Creative Commons Attribution (CC-BY) license (http://creativecommons.org/licenses/by/4.0/). 